\title{
REFORM BY LEGAL TRANSPLANTATION: AFGHANISTAN'S COUNTER NARCOTICS LAW 2006
}

\begin{abstract}
When the international community has engaged in efforts to assist transitions to peace in countries de-stabilized by conflict, new criminal law is often found to be imperative in order to promote the development of fair and effective justice systems, the rule of law and due process in accordance with international human rights standards. While the transplantation of readily available law can be an appealing solution, little scholarship has been dedicated to examining its effectiveness for developing post-intervention criminal law reform. Informed by empirical evidence and qualitative interviews with senior international and Afghan legal personnel, this article addresses this gap in scholarship by evaluating Afghanistan's Counter Narcotics Law 2006 (CNL). Applying a new test, it considers firstly, whether this law was a successful transplant and, secondly, whether it was reasonable for those responsible for drafting it to rely on legal transplantation as a mechanism for reform. It finds that the transplanted content of the CNL and the processes of transplantation reduced the extent to which it was accepted and achieved its objectives, and concludes by making recommendations for 'sensitive' transplantation based on knowledge of theoretical frameworks on transplant feasibility and legal adaptation, analysis of local legal traditions and collaboration with local justice professionals.
\end{abstract}

\section{Keywords}

legal transplants - criminal law - Afghanistan - law reform

* Lecturer in Law, University of Sussex, e-mail: j.jupp@sussex.ac.uk. 


\section{INTRODUCTION}

In states where the international community has engaged in efforts to assist in transitions from conflict to peace and promote the rule of law there is a noticeable trend of reliance by reformers upon legal transplants to stimulate legal change. This is certainly the case with substantive and procedural criminal law reform, often identified as the essential starting point on the road towards establishing the rule of law. ${ }^{1}$ The criminal law frameworks of Liberia, Angola, Bosnia, Haiti, East Timor, Kosovo, and Afghanistan ${ }^{2}$ all underwent extensive programmes of reform following international intervention, assisted by legal transplantation. This suggests that the normative reasoning of post-intervention law reformers is that legal transplants represent a legitimate means of promoting quick and necessary modification\{s?\} or replacements to old or inadequate laws in criminal justice systems often typified by a neglect of international human rights standards and by political distortion. This legitimacy may be rooted in the symbolic significance of a borrowed law, ${ }^{3}$ driven by the powerful forces of modernisation and globalisation ${ }^{4}$ or explained by the cost-saving expediency of importing tried and tested law when

${ }^{1}$ V. O'Connor, Rule of Law and Human Rights Protections through Criminal Law Reform: Model Codes for Post-Conflict Criminal Justice, "International Peacekeeping" 13:4, 2006, p. 527.

${ }^{2}$ For reform of the Liberian and Haitian criminal codes as well as the Angolan Penal Code see C. Rausch, Combatting Serious Crimes in Postconflict Societies. A Handbook for Policymakers and Practitioners (United States Institute of Peace 2006); for Kosovo, see UNMIK Regulations and Administrative Directions, Official Gazette, http:/ / www.unmikonline. org/regulations/index.htm; for East Timor see, e.g., On Transitional Rules of Criminal Procedure, UNTAET Reg. No. 2000/30 (25 September 2000) and On the Establishment of a Legal Aid Service in East Timor, UNTAET Reg. 2001/24 (5 September 2001); for Afghanistan, see, e.g., Interim Criminal Procedure Code, Official Gazette No. 820, 2004; Law on the Campaign Against Bribery and Administrative Corruption, Official Gazette No. 838, 2004; Law Combatting the Financing of Terrorism, Official Gazette no. 839, 2004; Law on the Campaign Against Money Laundering and Its Proceeds, Official Gazette No. 840, 2004.

${ }^{3}$ L. Friedman, Some Comments on Cotterrell and Legal Transplants [in:] D. Nelken and J. Feest (eds), Adapting Legal Cultures. Hart, 2001.

4 J. Miller, A Typology of Legal Transplants: Using Sociology, Legal History and Argentine Examples to Explain the Transplant Process "American Journal of Comparative Law", 51 2003, p. 839. 
urgent new legal frameworks are required. ${ }^{5}$ Dobbins has acknowledged the significant contributory value of legal transplants for the creation of quick-start packages of criminal laws ready for immediate application in post-intervention states. ${ }^{6} \mathrm{O}^{\prime}$ Connor's Model Codes for Post Conflict Criminal Justice certainly give sustenance to this reasoning. ${ }^{7}$

This means of criminal law reform has not been without its critics. Both Drumbl and Brooks have, rightly, cautioned against neutral, formalistic and technical approaches to rule of law reform that may rely on legal transplantation and are detached from social or political consequences. ${ }^{8}$ In a similar vein, The UN's 2004 Rule of Law report similarly advised Member States to 'eschew one-size-fits all formulas and the importation of foreign models. ${ }^{9}$ This instruction contrasted sharply with earlier recommendations to look to 'foreign models and foreign-conceived solutions ${ }^{\prime 10}$ and with the reality on the ground, as a flurry of newly transplanted laws was simultaneously being introduced in Afghanistan following significant input from international experts. ${ }^{11}$

The lack of real consensus amongst practitioners about the benefits to post-intervention criminal law reform of legal transplants is mirrored by similar discord amongst academics as to their significance for promoting legal change and the conditions that contribute to their success or failure. These tensions largely reflect diverging perspectives over the relationship between law and society. For Legrand, the meanings of legal rules are so culture-specific that any attempt to transplant them into another

${ }^{5}$ H. Kanda, C. J. Milhaupt, Re-examining Legal Transplants: The Director's Fiduciary Duty in Japanese Corporate Law "American Journal of Comparative Law", 51 2003, p. 887.

${ }^{6}$ J. Dobbins, S. Jones, K. Crane, B. Cole de Grasse The Beginner's Guide to NationBuilding, Santa Monica, CA: RAND Corporation, 2007, p. 77.

7 O'Connor, supra note 1.

${ }^{8}$ M. A. Drumbl, Rights, Culture and Crime: The Role of Rule of Law for the Women of Afghanistan "Colombia Journal of Transnational Law", Issue 4 2004, p. 249; R. Brooks, The New Imperialism: Violence, Norms and the Rule of Law, "Michigan Law Review", Issue 101, 2002-2003, p. 2285.

${ }^{9}$ United Nations, Report of the Secretary-General: The Rule of Law and Transitional Justice in Conflict and Post-Conflict Societies, U.N. Doc. 5/2004/616 (23.08.2004).

${ }_{10}$ United Nations, Report of the Panel on United Nations Peace Operations: Comprehensive Review of the Whole Question of Peacekeeping Operations in All Its Aspects (Brahimi Report) U.N. Doc. A/55/305-S/2000/809 (21 August 2000).

11 supra, note 2 . 
jurisdiction renders them void of any meaning at all. The result is that legal transplantation is impossible. ${ }^{12}$ Watson's contrasting view of legal transplants places them at the forefront of legal development. For Watson, the statements and rules that comprise legal provisions are independent of cultural concerns. Moreover, the socio-political contexts of the original and recipient jurisdictions are of limited consequence to the manner in which transplanted rules are received. Therefore, the recipient system 'does not require any real knowledge of the social, economic, geographical, and political context of the origin and growth of the original rule. ${ }^{13}$ In addition, given that historical analysis demonstrates that legal transplants are responsible for legal development, the issue of whether a transplant is or is not successful is of little concern.

Watson's positivist outlook on the influence of legal transplantation on legal development is counter-balanced by socio-legal assessments advanced by a number of other prominent academics. These largely acknowledge the potential of legal transplants as stimulants for legal change, while asserting that the success or failure of transplanted law - and, therefore, whether it is appropriate to develop law by legal transplantation - will be dependent upon a variety of sociological, cultural, political, and economic influences. Kanda and Milhaupt have emphasised the need to find 'the right plot' for a transplanted law. ${ }^{14}$ Successful transplantation depends on the fit between the host environment and the adopted rules. Similarly, Brooks warns that law reformers in post-intervention states have little prospect of their new transplanted laws creating or changing intended legal rules and procedures unless they 'know the culture and take it seriously.' ${ }^{15}$ The local context of the recipient jurisdiction is, therefore, the key determinant of success for legal development. For deLisle, also, the successful importation of legal transplants is tied to the approximation of the transplant to the legal culture of the importing country. More than this, however, close

12 P. Legrand, What 'Legal Transplants'? [in:] D. Nelken and J. Feest, (eds), Adapting Legal Cultures, Hart, 2001.

13 A. Watson, Legal Transplants and Law Reform, "Law Quarterly Review" Issue 92, 1976, p. 81.

${ }^{14}$ Kanda and Milhaupt, supra note 5, at p. 887.

15 Brooks, supra note 8 at p. 2334. 
collaboration between the domestic and foreign legal experts involved at the time of its importation is likely to condition its reception. ${ }^{16}$

These contrasting theoretical views on the value, feasibility, and evaluation ${ }^{17}$ of legal transplants, as well as conflicting recommendations amongst practitioners over their legitimacy, and a rudimentary understanding amongst international advisers as to their viability, combine to provide little reassurance to law reformers as to their potential for promoting effective post-intervention criminal law reform. Part of the problem is that there is a lack of authoritative empirical evidence and evaluative studies from which to draw reference and learn valuable lessons. The Department for International Development has acknowledged that 'many initiatives in the justice sector have not been subject to careful monitoring and evaluation.' ${ }^{18}$ Similarly, the UN's Rule of Law report lamented the 'scant attention' ${ }^{19}$ that has been paid to the post-conflict rule of law reform, an observation supported by Samuels, who has noted that in spite of more than twenty years of experimenting 'little is known about how to bring about legal change in developing or post-conflict countries. ${ }^{20}$

Empirically informed by a wide range of sources, including data from Afghan Justice Ministries and interviews with more than 20 senior international and Afghan legal personnel, this article aims to fill an important gap in existing scholarship by shedding new light on the complex role of legal transplantation for post-intervention legal development by evaluating Afghanistan's Counter Narcotics Law (CNL), ${ }^{21}$ passed by Presidential decree in 2005 and later replaced by new legislation in 2010.

${ }^{16}$ J. deLisle, Lex Americana?: United States Legal Assistance, American Legal Models and Legal Change in the Post-Communist World and Beyond, "University of Pennsylvania Journal of international Economic Law", Issue 20, 1999, p. 280-1.

${ }^{17}$ J. Jupp, Legal Transplants as Tools for Post-Conflict Criminal Law Reform: Justification and Evaluation, "Cambridge Journal of International and Comparative Law," Issue 3, 2014, p. 392.

${ }_{18}$ Department for International Development, Safety, Security and Accessible Justice: Putting Policy into Practice, (July 2002).

${ }_{19} \mathrm{UN}$, supra note 9, at para. 24

${ }^{20}$ K. Samuels, Rule of Law Reform in Post-Conflict Countries. Operational Initiatives and Lessons Learnt (Social Development Papers. Conflict Prevention and Reconstruction. Paper No. 37, 2006), p. 18.

${ }^{21}$ Counter Narcotics Law, Official Gazette No. 875, April 2, 2006. 
The CNL provides a relevant and illuminating example of a criminal law transplanted in a post-intervention state as part of a programme of criminal law reform which, to date, has eluded any scholarly analysis. A new evaluative test is applied to the CNL in order to examine two central questions: firstly, whether the CNL was a successful legal transplant and secondly, whether it was reasonable for legislators to rely on legal transplantation to develop this law when seeking to reform Afghanistan's criminal law framework in order to promote the rule of law. In tackling these issues this article provides new insight into the impact of this transplanted law on criminal justice reform in Afghanistan and produces findings which have important ramifications for both legal reform policy in post-intervention states and for theoretical frameworks on transplant feasibility and legal adaptation.

The evaluative test that is applied seeks to balance positivist and socio-legal perspectives on legal development and considers: firstly, whether it was accepted by the local population, bearing in mind the manner in which it was applied and the extent to which it was regarded as meaningful and appropriate by those applying it and those subject to its provisions; and secondly, whether it achieved its objectives. It proposes that the greater the extent to which the CNL was accepted and achieved its objectives, the more compelling it is to conclude that it was a successful legal transplant.

To further elucidate the first of the two arms of this test, namely the acceptance of a transplanted law, this is irrevocably linked to the manner in which it is applied by local law enforcement personnel and lawyers. ${ }^{22}$ It is more likely to be applied, and therefore accepted, if it is valued and considered to be meaningful and appropriate to those applying it. The more familiar the legal authorities of the recipient country are with the transplanted legal concepts, the more likely it is that they will be successfully adopted and applied. This reasoning acknowledges Watson's contention that law is ultimately shaped by elite legal professionals. It also resonates with Brook's work on 'norm-change' promotion in rule-of-law projects ${ }^{23}$ and with Dezalay's premise that the success of

22 J. H. Beckstrom, Transplantation of Legal Systems: An Early Report on the Reception of Western Laws in Ethiopia, "American Journal of Comparative Law", Issue 21, 1973, p. 561.

${ }^{23}$ Brooks, supra note 8, p. 2286. 
a transplant is tied up in the extent to which local society will deem it worthy of investment. ${ }^{24}$

The second arm of this test considers the extent to which a transplanted law has achieved its objectives. If law reformers choose to rely on legal transplants as mechanisms for legal reform, it is reasonable to assume that they do so with specific objectives in mind which they believe the transplanted law can fulfil. An assessment of these identifiable objectives and the extent to which they have been met allows for consideration of the particular country-specific, post-intervention complexities with which law reformers are faced when drafting new law.

To achieve its aims the article introduces the CNL in Part 1 and identifies the features that confirm it to be a legal transplant. Part 2 acknowledges a number of challenges to its reception, rooted in Afghanistan's plural legal traditions and a weak centralised state justice system. Part 3 applies the author's evaluative test to the CNL and details important findings, and the article concludes with Part 4, which outlines the implications of the study's findings for theoretical debates on legal transplants and post-intervention law reform policy.

\section{PART I}

\section{The Counter Narcotics LaW 2006 AS A LEGAL TRANSPLANT}

The passing of the CNL was to a large extent a reaction to the failure of counter-narcotics reform initiatives undertaken by the Afghan government and its international supporters between 2001 and 2005. In May 2003 a 5-year National Drug Control Strategy (NDCS) was adopted following extensive consultation with international experts from the US, the UK, and the United Nations Office on Drugs and Crime (UNODC) ${ }^{25}$ which contained the ambitious objective of reducing opium cultivation

${ }^{24}$ G. Dezalay, The Import and Export of Law and Legal Institutions [in:] D. Nelken and J. Feest (eds), Adapting Legal Cultures, Hart, 2001.

${ }^{25}$ C. M. Blanchard, Afghanistan: Narcotics and U.S. Policy [in:] L. V. Barton (ed.) Illegal Drugs and Governmental Policies, New York: Nova Science Publishers, 2007, p. 116. 
by $70 \%$ by 2008 and eliminating it by $2013^{26}$, and identified judicial reform as one of five key areas on which to concentrate efforts to facilitate this. ${ }^{27}$ In this respect it recognised 'the need for [the] establishment of an efficient and modern criminal justice system to address drug trafficking' and promised that 'proper laws would be enacted,' ${ }^{28}$ which would include a 'national law on drug trafficking and related offences' in the drive towards establishing an 'anti-drugs legislative system that meets international standards. ${ }^{29}$

The result was a new Counter Narcotics Law passed in October 2003, drafted quickly with very little input from or consultation with local representatives ${ }^{30}$, and transplanted from a UN 'model' law with deliberate omissions in order, apparently, to make it more understandable to Afghan practitioners. ${ }^{31}$ This represented a diversion from the previous 1991 law which, according to one international expert, was 'basic, and just imposed imprisonment for trafficking and cultivation. ${ }^{32}$ The new law provided for the regulation of illicit drug-related offences and the classification of drugs and precursors in accordance with internationally approved standards. However, by late 2004, according to the United Nations Assistance Mission in Afghanistan (UNAMA), there was 'a consensus that the [CNL 2003] needed revision.' ${ }^{33}$ It failed to provide the police and prosecutors with the necessary modern mechanisms required to successfully apprehend and convict drug traffickers, particularly those

${ }^{26}$ National Drug Control Strategy 2003, p.9, available at online:<www.cicad.oas/ fortalecimiento.../National\%20Plans/USA\%2003.pdf [last accessed 19.03. 2019].

${ }^{27}$ Ibid. The others being institution building, law enforcement, alternative livelihoods, and demand reduction.

${ }^{28}$ Ibid., at annex p.v.

${ }^{29}$ Ibid., at annex p.vi.

${ }^{30}$ email correspondence, International Drugs and Development Adviser; it 'is drafted by "experts" from UNODC' who had only two visits with the Afghan delegates in order to draft the legislation. According to this source those involved with the law were required to draft it within a very short time-frame, which may have accounted for the minimal consultation with local actors.

${ }^{31}$ Ibid.; the interviewee stated that 'the 2003 law ... is based on the UN "model" law, but with several omissions due to the lack of any Afghan understanding of what it is.'

32 Ibid.

33 United Nations Assistance Mission in Afghanistan (UNAMA), Justice Sector Overview, April 2007, held on file, at 7. 
at the top end of the trade with international connections who were adopting increasingly sophisticated trafficking strategies. A new law could provide police and prosecutors with more modern tools to deal with counter-narcotic crime. ${ }^{34} \mathrm{New}$ initiatives were required.

By this stage it was clear that counter-narcotic strategies were failing. There were at least 15,000 opium traders and approximately $10 \%$ of the total population were involved in poppy cultivation. ${ }^{35}$. Opium production was estimated at 4,200 tons, 23 times more than that produced 20 years earlier. ${ }^{36}$ Profits from the narcotics trade were worth \$US2.2 billion a year and the industry had become deeply interwoven with not only the economic, but also the political and social fabric of the country. Opium was being cultivated in all of Afghanistan's provinces and profiteering from its production was financing insurgency, encouraging corruption, and increasing warlord power, which combined to represent a huge threat to domestic state-building and rule of law reform efforts. ${ }^{37} \mathrm{UNODC}$ warned that 'unless the drug problem is solved, there would be no sustainable development for Afghanistan.' ${ }^{38}$

The CNL was introduced as a legislative solution to Afghanistan's 'drug problem.' In recognition of the spiralling narcotics problems, the Afghan government published a Counter Narcotics Implementation Plan in February 2005, following a period of consultation with international experts, which set out eight pillar activities designed to tackle the cultivation, production, and trafficking of drugs in Afghanistan. The pillar concerned with 'criminal justice' identified a number of key targets,

34 According to the NDCS 2006 although the 2003 CNL 'is a major step forward compared to previous legislation ...it did not address the 'working needs' of drug law enforcement officials;' see National Drug Control Strategy 2006, p. 45, available at www. fco.gov.uk/resources/en/pdf/pdf18/fco_nationaldrugcontrolstrategy [last accessed 9 March 2019].

35 W. Byrd, C. Ward, Afghanistan's Drug Economy. A Preliminary Overview and Analysis, Draft Technical Annex 2, Ishington: World Bank, 2004.

${ }^{36}$ UNODC, The Opium Economy in Afghanistan. An International Problem, 2003, p. 81, available at reliefweb.int/w/rwb.../214e1694bbf78591c1256cc60049f953? [last accessed 9 March 2019].

37 UNODC, World Drug Report 2005, p. 179, available at www.unodc.org/pdf/ WDR_2005/volume_2_chap5_opium.pdf [last accessed 9 March 2019].

${ }^{38}$ Ibid at 210. 
amongst which were the development of 'a more effective criminal justice system,' (a tacit admission that the prevailing system was inadequate), the establishment of a new Court and prison in Kabul dedicated to major drug trafficking cases, and the introduction of 'an effective counternarcotics legal framework' ${ }^{39}$

In alignment with these requirements, a centralised counter-narcotics Criminal Justice Task Force (CJTF) was established by the Afghan government in co-operation with the UK and with support from the US and UNODC, becoming fully operational in July $2005 .{ }^{40}$ UK representatives noted that 'in a climate where counter narcotic law is largely unimplemented, ... a dedicated, highly-mentored unit is essential to deal effectively with serious counter narcotic-related crime, and demonstrate to traffickers they were at real risk of prosecution. ${ }^{\prime 41}$ The CJTF was composed of specialist investigators, prosecutors, and judges trained to expedite significant counter-narcotics cases. ${ }^{42}$ The result of this revised counter-narcotics programme was the creation of an integrated system of criminal justice that would exist parallel to the existing poorly functioning justice system and which would be specifically dedicated to drug-related criminal cases capable of being fast-tracked through new centralised courts, namely the Central Narcotics Tribunal (CNT) Primary and Appeal Courts, devoted solely to narcotic-related crime. A new counter-narcotics law was required, one that would be the centre-point of these new initiatives and which would also have the pragmatic significance of establishing the jurisdiction of the CNT by law and formalising the statutory powers of the Ministry of Counter Narcotics (MCN), founded in December 2004 to co-ordinate counter-narcotics activities. ${ }^{43}$ This was to be the CNL.

39 The Counter Narcotics Implementation Plan, 16.02.2005, available at www. afghanemb-canada.net/en/counter_narcotics [last accessed 15.03.2019].

${ }^{40}$ UNAMA, supra note 33 at p. 33.

${ }^{41}$ The Criminal Justice Task Force - Lessons Learned, Conference on the Rule of Law in Afghanistan, Rome 02.07.2007, held on file, at p. 1.

${ }^{42}$ Its jurisdiction, defined in the CNL 2005, extends to any case where the amount of heroin, morphine, or cocaine seized exceeds $2 \mathrm{kgs}$, opium exceeds $10 \mathrm{~kg}$, or hashish or other specified illegal substances exceeds $50 \mathrm{~kg}$ (article 34(4)(a)-(c).

${ }^{43}$ Interview, International Drugs and Development Adviser. Although the MCN was formed in early 2005 and had two Deputy Ministers it had not yet been accorded any formal statutory powers. 
While it was a product of collaboration between the UK, the US, and Afghanistan, the CNL was regarded locally as an internationally-led law, ${ }^{44}$ a perception heightened by the fact that it was drafted in English as opposed to Dari or Pashto. ${ }^{45}$ In reality, it was largely designed by the UK and the US. The UK had a larger input with the operational sections of the law, such as the provisions dealing with electronic interception and surveillance, which were new counter-narcotic legal concepts in Afghanistan. ${ }^{46}$ The US were intent on imposing mandatory sentences for drug offences and providing for the extradition of suspects for trial abroad, both of which were included in the final draft. ${ }^{47}$ The first draft was prepared by members of the Drugs Team from the UK Home Office stationed at the UK Embassy in Kabul in 2005. ${ }^{48}$ They were not, however, trained lawyers ${ }^{49}$ and the UK acknowledged that it lacked the necessary personnel to competently complete the drafting process, at which point it sought the assistance of two US Department of Justice Deputy District Attorney-Generals (who had been working alongside various retired military policemen), US Drug Enforcement Administration (DEA) agents, Norwegian judges, and lawyers employed as mentors within the CJTF. ${ }^{50}$

There were opportunities for Afghan involvement in the drafting process. The UK was assisted by Dr Adbul Jabar Sabet, later to be appointed Attorney-General, but who in 2005 was acting as both a legal adviser to the Ministry of Interior (MOI) and the UK Drugs Team, with which he had a very close working relationship..$^{51}$ The UK provided Sabet with a framework for the law and asked him to review it, applying his experience of domestic criminal and counter-narcotics law. ${ }^{52}$ Some additional personnel in the Attorney General's Office (AGO) followed the legislation in its drafting stages through to its enactment. To that extent

\footnotetext{
${ }^{44}$ Interview, senior member of the UK Rule of Law team.

${ }^{45}$ UNAMA, supra note 33 , at p. 7.

${ }^{46}$ Interview, supra note 43.

47 Possibly because US personnel were more involved than UK Home Office actors at the end point of the drafting process; interview, supra note 44 .

48 Ibid.

49 Interview, senior prosecutions adviser.

${ }^{50}$ Interview, supra note 44.

51 Ibid.

52 Ibid.
} 
Sabet and the AGO had every reasonable opportunity to approve or amend the CNL before it was passed by Presidential Decree in December 2005.

As it turned out, however, the contribution of the AGO and also the Afghan Supreme Court to the drafting stages proved to be relatively minor, confined principally to ensuring that it included a rigorous sentencing structure, which emerged as the primary concern of Afghan contributors to the process. ${ }^{53}$ It has since been noted that any local opposition to the provisions proposed in the draft law were 'silenced' during meetings with international agents. ${ }^{54}$ The comparatively inconsiderable role played by Afghan actors in the drafting stages of the CNL may have been due to a lack of professional capacity within the AGO and the Supreme Court. It was apparent to the international actors at the time that there is not a great wealth of legislative reform experience amongst those Afghan officials who might have been in a position to contribute to the process. ${ }^{55}$ Additionally, there may have been a lack of willingness amongst domestic actors to contribute meaningfully to the drafting task. It would have distracted them from their other administrative responsibilities, and exposed them to criticism if the law was later construed as being flawed. ${ }^{56}$ It is likely also that the 'lead nation' policy, installed following the Tokyo Conference ${ }^{57}$, generated a culture of dependence by domestic officials on the experience of international actors to complete technical and demanding tasks of this nature.

It is equally possible that the potential for greater Afghan contribution was compromised by the speed with which the CNL was drafted and passed. It was, a senior prosecution adviser with the British Embassy

${ }^{53}$ Interview, senior member of the UK Rule of Law team, 25.03.2008.

${ }_{54}$ M. E. Hartmann, A. Klonowiecka-Milart, Lost in Translation. Legal Transplants Without Consensus-Based Adaptation, [in:] W. Mason (ed.) The Rule of Law in Afghanistan: Missing in Inaction, Cambridge University Press, 2011, at p. 289.

${ }^{55}$ Interview, supra note 44.

56 Ibid.

57 The 'International Conference on Reconstruction Assistance to Afghanistan,' Tokyo, 21-22 January 2002, held at ministerial level and co-chaired by Japan, US, EU, and Saudi Arabia. See Consulate General of Japan in New York, Japan Info: Tokyo Hosts International Conference on Reconstruction Assistance to Afghanistan, available at www.cgi.org/en/c/ vol_09-5/title_02.htm [last accessed 15.03.2019]. 
Drugs Team later reflected, 'too rushed'. ${ }^{58}$ There was a sense of urgency about the drafting process given the recognised demand amongst the UK and international donors in particular for a new counter-narcotics law that would complement the revised strategy that envisaged a new justice system dedicated to drug crime, augmented by the CJTF, the CNPA, and new courts. But the speed with which it was prepared was, in all likelihood, also the result of political ramifications. Once Parliament returned, it would have to be considered by the Taqnin, ${ }^{59}$ entailing a lengthy consultation process and inevitable postponement of the potential impact of the new counter-narcotics policy. Ultimately it was passed by Presidential decree just one day before Parliament was due to convene.${ }^{60}$ In fact, then, the drafting process of the CNL 2005 was similar to that of its predecessor. It was drafted quickly, based on international models and contained provisions conforming to international conventions.

Given the combination of all of these factors, the CNL 2005 contains many of the hallmarks of a legal transplant. It established internationallyfunded centralised institutions. The new judges, police, and prosecutors employed by these institutions would be trained by international organisations and placed under foreign scrutiny and invigilation. There was only marginal input by or consultation with local actors during the drafting stages. It may have been a piece of Afghan legislation, but it was regarded as an international law that fundamentally includes borrowed foreign principles of acceptable counter-narcotics law, drafted in a foreign language mainly by foreign actors.

\section{PART II. CONStRaints ON Reception}

The CNL was introduced in Afghanistan in 2005, four years into a process of international engagement in assisting in reconstructing the state justice sector. At the time, the central administration and its international donors faced significant challenges, characterised by damaged infrastructure,

\footnotetext{
58 interview, supra note 49.

59 The Taqnin is the legislative drafting unit based in the Ministry of Justice.

${ }^{60}$ Interview, supra note 43.
} 
uncertain knowledge of relevant applicable laws, and poor capacity amongst justice and law enforcement personnel. ${ }^{61}$

Legal training and capacity building programmes were undertaken by a large number of international donors, initially under a 'lead nation' strategy which saw the UK assume responsibility for counter narcotics. However, there was a lack of any real co-ordination between them, and also insufficient Afghan involvement. While the reconstruction strategy changed in 2007 to allow for greater local engagement in the reconstruction process, it remained largely controlled by international donors, and particularly by the US during the period of the CNL's existence. ${ }^{62}$ An international emphasis on security over justice and rule of law and pervasive corruption and abuse of power within justice institutions increased local disillusionment in the state criminal justice system, driving insurgency, and in turn undermining state justice mechanisms and legislative reform. These contemporary challenges to the state justice system are likely to have challenged the application and reception of new transplanted laws such as the CNL.

It is also worth noting that the reach of the central state and its ability to impose its criminal justice system on the rural population has been challenged by a history of local reservations over its legitimacy brought about by persistent reliance by Afghan rulers on foreign assistance. Rather than gaining authority based on support from within Afghanistan, those in control of the state - and state justice mechanisms - have long been dependent on financial assistance from external powers. Abdul Rahman Khan, under British sovereignty, relied on British arms to strengthen his state system. Between 1955 and 1978 the Soviet Union provided US $\$ 2.52$ billion and the US $\$ 533$ million in aid to support state rulers ${ }^{63}$ and the mujahedeen were later supported by the US and Saudi Arabia during Soviet occupation. The current regime, under President Karzai,

${ }_{61}$ T. J. Barfield, On Local Justice and Culture in Post-Taliban Afghanistan, Issue 17, 2001-2002, p. 437-443.

${ }^{62}$ M.C. Bassiouni, D. Rothberg, Assessment of Justice Programs and Rule of Law Reform in Afghanistan and Future Directions, 2 July 2007, p. 5, available at www.rolafghanistan. esteri.it/ConferenceRol/Menu/Ambasciata/Gil_uffici/ [last accessed 15.03.2019].

${ }^{63}$ B. R. Rubin, The Fragmentation of Afghanistan. State Formation and Collapse in the International System, Yale University Press, 1995, p. 20. 
has received unprecedented levels of foreign financial assistance. It is estimated that $90-95 \%$ of all state development costs and $69 \%$ of all government expenditure is financed by external aid, more than under any other previous regime. ${ }^{64}$ The dependence by a succession of state rulers on foreign financial assistance to maintain power and control has resulted in a series of rentier states, particularly since 1978, propped up by external aid rather than by an internal base of support. This dependence increases doubt over whether measures introduced by the Afghan state are in the best interests of the Afghan people or are the result of manipulation by its foreign sponsors. There is considerable mistrust over the intentions of the foreign backers of the state. The collective experience of the Soviet invasion, the US abandonment of the country following Soviet withdrawal, the support provided by neighbouring countries to factions involved in the civil war, and the current intervention by international forces, which provides strategic access in the region, has created a deep suspicion that foreign powers support the Afghan state only to serve their own interests. ${ }^{65}$

These suspicions increase antipathy towards the state regime and its justice system, and reduce their legitimacy and reach, which continue to remain largely confined to urban areas. The formal system of justice is relevant for only $10 \%$ of the population. ${ }^{66} \mathrm{It}$ is, as the EU has acknowledged, 'far removed from ordinary people's everyday life' ${ }^{67}$ The legitimacy of the state justice system, limited by a devastated infrastructure, the corrupt practices of some of its officials whose capacity is questionable, and fluctuating regime change has contrasted unfavourably with the permanency and relevance of Shari'a and customary practices whose authority derives from the more meaningful sources of religion and the collective requirements of the local community. The Afghan state, Misdaq

64 A. Suhrke, The Case for a Light Footprint: The International Project in Afghanistan 2010, Anthony Hyman Memorial Lecture, SOAS, 17 March 2010, available at www.soas.ac.uk/ cccac/events/anthonyhyman/file58420.pdf [last accessed 15.03.2019].\% \% \%

65 A. J. Their, Re-establishing the Judicial System in Afghanistan, CDDRL Working Paper, no.19, 1 September 2004, p. 5, available at www.cddrl.stanford.edu [last accessed 15.03.2019].

${ }^{66}$ European Commission, EU Commitment to the Governance and Rule of Law in Afghanistan, July 2007, p. 11.

67 Ibid at 6. 
reminds us, has always been 'in the shadow of the tribe. ${ }^{\prime 68}$ And so, state law has always lived in the shadow of Shari'a and customary law. Tribal, ethnic, and religious affiliations and consequent customary and Islamic practices have more resonance and greater appeal to the majority of the local population. As a result, the norms and rituals provided for in any state law in Afghanistan, are traditionally rarely 'widely shared' by the local population.

These historical issues are likely to impact on the potential reception of state laws such as the CNL. If state laws have traditionally had less appeal to Afghans, new transplanted state laws are less likely to be considered meaningful and appropriate to them, with the result that the laws are consequently less likely to be accepted and to achieve their objectives.

Given that the evaluative test that is to be applied to the CNL requires a consideration of socio-legal influences, we might also reflect on the cultural challenges to transplant reception in Afghanistan. Local resistance to foreign conquest and intrusion and to foreign promoted attempts at state modernisation might imply a cultural resistance in Afghanistan to any new transplanted law such as the CNL, dependent on foreign sources, which would impact on its application and acceptance. Cultural resistance to a transplant may adversely affect its potential reception. ${ }^{69}$ What, however, is meant by 'culture' and indeed 'Afghan culture' by which it is possible to determine if there might be any cultural resistance to these transplanted laws? The concept of 'culture' is complex and difficult to define. According to Williams it is 'one of the two or three most complicated words in the English Language. ${ }^{70}$ A traditional 'natural history' anthropological approach to defining culture implies that it is handed down, preserved, fixed, and perhaps an obstacle to change. ${ }^{71}$

${ }^{68}$ N. Misdaq Afghanistan, Political Frailty and Foreign Interference, Routledge, 2006, p. 4.

${ }^{69}$ L. Marafioti, Italian Criminal Procedure: A System Caught Between Two Legal Traditions, [in:] J. Jackson, M. Langer, P. Tilliers (eds), Crime, Procedure and Evidence in a Comparative and International Context: Essays in Honour of Professor Damaska, Oxford UK: Hart Publishing, 2008, p. 81-98.

${ }^{70}$ R. Williams, Keywords: A Vocabulary of Culture and Society, Oxford University Press, 1983, p. 76.

${ }^{71}$ N. Dupree, Security with a Human Face; Challenges and Responsibilities. Afghanistan National Human Development Report 2004, UNDP 2005, p. 233. 
This perspective might suggest that any legal transplant that fails to be attuned to the culture of its host country is likely to meet resistance. It is an outlook, however, that has recently been challenged. Current anthropological approaches towards culture tend to regard it not as an essential, inherited, fixed tradition, but rather as something that is flexible and capable of change. Tapper's 2008 review of Afghan culture supports this stance. ${ }^{72}$ While Tapper maintains that it is not possible to say with any authority what culture or indeed Afghan culture actually is, it is nevertheless more likely to be 'a dynamic, changing, flexible collection of values and practices. ${ }^{173}$ In contrast to the natural history perspective, Tapper's view of Afghan culture would auger well for the potential receptivity of the $\mathrm{CNL}$, intent on bringing about change. Rather than being fixed and inflexible Afghan culture may be capable of negotiation and alteration and therefore of absorbing new, transplanted legal concepts and procedures.

\section{Part III. Evaluating the Counter NARCOTICS LAW 2006}

\section{A. The Application of the LaW}

By February 2010 the CJTF, which applied the CNL with respect to more significant drug cases under article 34, was situated within a \$US 12 million compound in central Kabul and comprised over 150 staff. These included 40 CNPA investigators from the MOI and 35 prosecutors seconded from the AGO, all of whom were selected on the basis of ability and integrity. There were also 13 Judges provided by the Supreme Court, seven of whom presided at the Primary Court and 6 at the Appeal Court. ${ }^{74}$ A Detention Centre, staffed by personnel from the Central Prison Division under the aegis of the MOJ, was situated in the compound, containing 50 beds for detained suspects. There were also barracks for the prison

72 R. Tapper, What is Afghan culture? An anthropologist reflects, Anthony Hyman Memorial Lecture, SOAS, 13 March 2008.

73 Ibid.

${ }^{74}$ Figures provided by FCO official based at the CJTF during interview on 23.02.2010. 
staff and a Judicial Security Unit responsible for maintaining the security of the compound, ensuring the protection of Judges and staff and the safe transfer of prisoners on site. All of the units in the compound were built as separate entities. Therefore, police investigators worked in one building and Judges in another in an effort to preserve the integrity and independence of the departments engaged in applying the law. ${ }^{75}$

There were four different types of Prosecutors based at the CJTF who were applying the CNL. Investigative prosecutors conducted all the necessary investigations in relation to a drugs case which came under its jurisdiction. This involved their working closely with the police during the questioning and interrogation of a suspect, attending crime sites, and viewing drug hauls. Investigations were to be concluded within 15 days of receiving a case, although prosecutors were able to apply for an extension of time for up to 15 days on application to the Court. ${ }^{76}$ At the end of the prescribed investigative periods, which could not exceed 30 days, the investigative prosecutor should either have released the suspect or served him/her with an indictment. This consisted of 6 to 7 pages of script detailing the case against the accused, which was served on them and filed at Court. Cases were to be timetabled with lists published and made available to the accused and defence lawyers and trial dates set down within 2 months of the service and filing of an indictment. ${ }^{77}$ The CJTF tried to ensure that defence lawyers to whom drug cases were referred were members of the Afghanistan Independent Bar Association (AIBA) as it imposed a code of conduct and ethical standards. ${ }^{78}$ In practice, there tended to be a select group of defence lawyers affiliated with the Bar Association to whom cases were referred on a regular basis. ${ }^{79}$

UK mentors worked with the prosecutors to try to change a predisposition for automatic referral of cases to trial having noted that some prosecutors, and particularly those who were trained in Moscow

${ }^{75}$ Interview, supra note 74 .

${ }^{76}$ Investigations and prosecutions were conducted in accordance with article 36 of the Interim Criminal Procedure Code, article 37(9).

77 Interview, supra note 74 .

78 The Afghanistan Independent Bar Association was formed in September 2008 further to the Advocates Law (November 2007). A Code of Conduct was approved in January 2009.

${ }^{79}$ Interview, supra note 74. 
or in Afghanistan under the Soviet court system, had a propensity to refer cases without proper assessment of the evidence and prospects of securing a conviction. ${ }^{80}$ Procedural changes were introduced to ensure that cases were properly reviewed before a decision was taken to set a matter down for trial and, by 2010, it was estimated that approximately $85 \%$ of the cases received by the CJTF proceeded to trial. ${ }^{81}$

If an indictment was served, the case was transferred to a Primary Prosecutor who would present the case for the prosecution at the trial. At the end of the trial, Judges retired to chambers to deliberate and agree a finding. If they found the defendant guilty, they would also determine the sentence at that stage. The judgement and sentence would usually be confirmed in writing. ${ }^{82}$

If the matter was appealed, which according to a senior CJTF prosecutor tended to be 'inevitable, ${ }^{\prime 83}$ it was referred to the CNT Appeal Court. The prosecution file would be transferred to the Appellate Prosecutor, who assumed responsibility for preparing and presenting the case for the prosecution at the appeal hearing that was to be conducted within 2 months. ${ }^{84}$ At the end of the appeal process, the accumulated prosecution case file would be passed to trial prosecutors. They scrutinised the paperwork and the procedures that had been followed, and prepared cases for trial at the Supreme Court if cases were referred for further appeal, which in practice was relatively rare. ${ }^{85}$

The CNL contained penalties of imprisonment that related in practice not only to cases involving the possession and trafficking of large quantities of narcotic drugs, which were referred to the CNT, but also to low-level drug offences dealt with in Provincial Courts, involving the use or possession of small quantities of drugs. There were concerns that the sentencing provisions were excessively harsh and failed to enable an appropriate degree of judicial discretion. ${ }^{86}$ Imprisonment appeared

\footnotetext{
${ }^{80}$ Interview, CNTF prosecution casework adviser.

81 Ibid.

${ }^{82}$ Interview, supra note 74 .

${ }^{83}$ Ibid.

84 Ibid.

85 Ibid.

${ }^{86}$ Ibid. Chapter IV, articles 15-33.
} 
unavoidable under the law, even for possession of small quantities of illicit drugs. Article 27, for example, failed to define any lower limit for possession entailing imprisonment. The result was that the possession of small amounts of cannabis amounting to less than 10 grams attracted a term of imprisonment of between 3 to 6 months in addition to a fine. ${ }^{87}$ Article 29 demanded that the Courts imposed maximum penalties in relation to offences committed by repeat offenders. ${ }^{88}$ Furthermore, detainees sentenced to more than 5 years imprisonment were denied any right to apply for home leave ${ }^{89}$ and drug trafficking offenders were prohibited from applying for probation or the suspension of their sentences, irrespective of the type of drug and the quantities involved or the circumstances of their offence..$^{90}$ According to UNODC, 'the principle that underlies the CNL is punishment. ${ }^{\prime 91}$ The punishment that was meted out was often in the form of lengthy prison sentences. Statistics published by the Supreme Court on selected decisions for the 8 month period between August 2008 and March 2009 revealed that 166 defendants were convicted of 'drugs narcotic crime' and convicted to a total of 1,756 years in prison, representing an average sentence of ten and a half years imprisonment per defendant. ${ }^{92}$

Drug trafficking offences resulted in mandatory prison sentences. Yet the majority of drug trafficking offenders to whom the law applied in practice were couriers, paid small sums of money to transport drugs. It would not be unreasonable, for instance, for a courier to receive approximately $\$ 500$ for transporting more than 10 kilos of heroin, which carried a mandatory life sentence..$^{93}$ The draconian sentencing provisions in article 16, largely reduced to a simple consideration of the weight of

${ }^{87}$ Article 27.
${ }^{88}$ Article 29.
${ }^{89}$ Article 30.
${ }_{90}$ Article $31(2)$.
${ }_{91}$ UNODC Afghanistan. Implementing Alternatives to Imprisonment, in line with International Standards and National Legislation, 2008, p.24, available at www.unodc. org/documents/justice-and-prison-reform/Afghanistan_Implementing_Alternatives_ Imprisonment.pdf [last accessed 19.03.2019].

92 Statistics available at www.supremecourt.gov.af/decision/decision.html [last accessed 19.03.2019].

${ }_{93}$ Interview, supra note 49. 
the drugs that have been seized, allowed little room for prudent judicial consideration relative to the degree of criminal responsibility. There was no hope for leniency for a courier, irrespective of the extent of their involvement in the crime.

A number of interviewed experts expressed concern over the CNL's sentencing structure. A CNT judge observed that the most serious problem with the law is 'the very harsh sentences that allow the judges no discretion.' ${ }^{94}$ A senior prosecution adviser reached the same conclusion, commenting that 'sentencing is robust and there is no real discretion. ${ }^{\prime 95}$ According to a senior prosecution caseworker at the CJTF, the 'massive minimum sentences' provided for in article 16 represented 'hard law [and] bad law', the practical effect of which is that couriers received lengthy prison sentences 'for effectively trying to get small amounts of money. ${ }^{96}$ There was no allowance for any balance between an offence and the suffering that should be imposed on an offender in order to secure justice. Ultimately, contrary to international recommendations, ${ }^{97}$ the CNL failed to provide an adequate level of proportionality between the nature of any drug trafficking offence and the degree of punishment that should be meted out.

In addition to concerns surrounding the tough sentencing provisions of the law, problems arose with the implementation of some of the 'new' procedures the CNL introduced. Article 41 provided incentives for apprehended and convicted drug offenders to co-operate with law enforcement agents, in return for which their sentences could be reduced by up to $50 \%$ on recommendation of the prosecutor in circumstances where an offender had provided 'substantial assistance' regarding the criminal activities of other suspects. This represented a new innovation for counter-narcotic law in Afghanistan, its rationale being that it would encourage offenders lower down the criminal chain, such as drugs couriers, to provide evidence against higher ranked drug offenders. No

\footnotetext{
${ }^{94}$ Questionnaire, CJTF Judge, 22.03.2009.

95 Interview, supra note 49.

${ }^{96}$ Interview, supra note 80.

97 See UN Human Rights Committee: Australia, 24.07.2000, A/55/40, paras 498-528, available at www.unhchr.ch/tbs/doc.nsf/.../A.55.40, paras498-528.En? [last accessed
} 15.03.2019]. 
similar provision existed in the applicable criminal procedure code upon which the law enforcement authorities could rely.

Officials, however, experienced difficulty in applying article 41, mainly as a result of its lack of prescription. It failed to set out any clear process for dealing with any new information provided by co-operating defendants. The reasoning of the law was undoubtedly that there should be a referral to the CNPA or international authorities so that they can make enquiries as to the authenticity of the information provided and that, if it proved to be helpful, this would be noted in the trial bundle with a recommendation for sentence reduction if the defendant was convicted. The article, however, did not prevent the information being made available to the Judge before reaching a judgement, influencing their decision-making regarding a defendant's innocence or guilt and increasing the potential for prejudicing judicial impartiality.

Article 41 also failed to provide any definition of 'substantial assistance,' leading to subjective interpretation by Primary Prosecutors. Furthermore, the English version of the law provided that the Primary Prosecutor had discretion to recommend a sentence reduction of up to $50 \%$ so that the discount would be relative to the amount and value of assistance provided. The Dari translation, however, stated that any sentence reduction should be $50 \%$ in all cases, removing any room for judicial discretion..$^{98}$ The intended application of the article was initially, therefore, lost in translation, making it susceptible to inconsistent application by the judiciary, until a ruling by the Supreme Court later clarified that sentence reductions were discretionary and up to $50 \% .{ }^{99}$

Aside from these problems, article 41 was open to abuse by offenders who, in the quest for sentence reductions, made false accusations against entirely innocent people, leading to their arrest. A CNT Judge commented that he did 'not like the Section 41 provision on informing on others as it provides an incentive to lie about people that you do not like and to get them into trouble with the authorities. ${ }^{\prime 100}$ An international expert also described the consequences of article 41 as 'a problem, a massive issue.

\footnotetext{
98 Interview, supra note 53.

99 Ibid.

100 CJTF Judge, supra note 94.
} 
The Sentencing Commission should be looking at it but do not have the personnel.' ${ }^{101}$

Not only did article 41 lead to the arrest of innocent people, but also the vital evidence against medium and higher-value drug traffickers that the drafters of the CNL might have anticipated also did not materialise to the extent that was hoped. In practice, applications for section 41 sentence reductions were invoked infrequently by defendants. A prosecution adviser attributed the 'uncommunicative' behaviour of defendants to a 'cultural' predisposition towards inscrutability rather than any reaction to the presence of international actors in the investigative and prosecution process. ${ }^{102}$ It was more likely, however, to be a direct response to threats to their safety and that of their families by personnel higher up the trafficking hierarchy. Higher-end drug traffickers were well aware of the potential dangers that article 41 might have presented to them and countered them by adopting 'scare and favour' strategies, which included issuing threats of harm and offering financial rewards. The latter often involved ensuring that the courier's family were looked after and provided for during their detention. Threats of harm, on the other hand, could be far reaching, and include killing not only a courier's partner and children but also all of their blood ancestors. ${ }^{103}$ These carrot and stick incentives were successful in frustrating law enforcement agents from benefiting from the sentence reduction incentives provided for in article 41 and, on the whole, it was not persuasive to couriers and lower-end targets (who were the most likely to be arrested and convicted) to provide vital evidence against key target large-scale drug traffickers.

Article 37 of the CNL also introduced new procedures to counternarcotic practices in Afghanistan and was one of the key centralising provisions of the legislation. It provided that upon the arrest of an individual with a quantity of drugs which ensured that the case fell within the jurisdiction of the CNL, the arresting officer should prepare a report and hand the accused over to the primary prosecutor of the district where the arrest took place within 72 hours. The accused was then to be transported by the CNPA to its headquarters in Kabul within

\footnotetext{
101 Interview, supra note 44.

102 Interview, supra note 43.

${ }^{103}$ Interview, supra note 44.
} 
15 days of the arrest, where the suspect could be held for questioning for up to 72 hours. Within 15 days of the arrest the case was to be handed over to a Special Counter Narcotics prosecutor entrusted with presenting an indictment to the primary CNT or, in the alternative, a further extension of time of 15 days should be sought to do so. ${ }^{104}$ The effect was that suspects arrested under the CNL were to be transferred to Kabul as soon as possible and no later than 15 days from their arrest.

Article 37 was designed to ensure that the administration of counternarcotic justice would be funnelled to special Courts in Kabul, staffed with specially trained judges and prosecutors cognisant with the law. The rationale behind this centralisation process was that it would enhance the potential for successfully prosecuting major drug cases and also help to ensure uniform application of the law. Suspects could be transported quickly from provincial areas to Kabul, where their cases would be placed under the scrutiny of the Counter Narcotics Trust Fund (CNTF). Prosecution cases would be managed by a small and select group of trained individuals. Hearings would take place in the same courts and the judges presiding over them would be conversant with the law and procedure and would quickly build experience, ensuring consistency in application of the law.

In reality, however, the article 37 provisions proved very difficult to implement. Transporting suspects from provincial areas within the timescales the article prescribed presented major logistical problems. Transport infrastructure in Afghanistan at the time was extremely poor. It had no functioning rail system, a limited and unregulated air transport service and possessed one of the worst and least developed road systems in the world. ${ }^{105}$ The potential for complying with the provisions of article 37 and securing a transfer of drug suspects within the prescribed time limits varied depending on where in the country an arrest was made. Different areas offered better or worse prospects for compliance, depending on available transport facilities. Rather than promoting the uniform application of the law in the manner that was anticipated by the drafters of the CNL, the difficult transfer requirements of article 37

104 Article 37(9).

105 Afghanistan Millennium Development Goals Report, 2005, p.xviii, available at www.ands.gov.af/mdgsgroups.asp [last accessed 16.03.2019] 
decreased the potential for consistency. A CNT Judge admitted that 'many times people were kept for longer than their time limits,' 106 representing worrying violations of defendants' rights to freedom from arbitrary detention as provided for in the Afghan Constitution and under international conventions to which Afghanistan was a signatory.

The CJTF, with UK mentor assistance, sought to solve the problem by airlifting prisoners from provincial areas to Kabul, often relying on assistance from the RAF. ${ }^{107}$ This, however, proved problematic because of the infrequency of available flights and the potential limited comparative priority airlifting prisoners represented to the air force relative to ongoing military commitments. Whilst the UK and the Afghan government were understood to have been considering employing a private contractor to airlift prisoners, there were disagreements about who should meet the costs of such an arrangement. It is understood that the UK funded the transporting of suspects in the face of reluctance from the Afghan government to contribute to costs, based on a reasoning that as the UK was responsible for the law, it should be liable for consequent expenses. ${ }^{108}$

Difficulties in organizing safe transport were not the only problems facing officials in their efforts to comply with article 37 requirements. Other variables affecting compliance included the degree of security in the area of arrest, the capacity of the police in the locality and their propensity to corruption. Most commonly, arrests took place when drugs were discovered during police or army checkpoints. Arrested individuals were to be handed to the CNPA as soon as possible and the matter referred to the primary prosecutor within 72 hours, whereupon arrangements were to be made for the transfer of the suspect to Kabul. Many cases, however, failed to be transferred either to the CNPA or Kabul owing to police corruption. ${ }^{109}$ There was provincial variation in compliance with the law. According to a senior member of the UK Rule of Law team interviewed in 2008 in Helmand, 'the likelihood of anything happening [in Helmand] is not great. What is more realistic...is that a bribe is paid to the policeman or [the case] is simply not progressed

\footnotetext{
${ }^{106}$ CJTF Judge, supra note 94.

107 Interview, supra note 44.

${ }^{108}$ Interview, supra note 43.

109 Interview, supra note 34.
} 
because I suspect that the police don't know what they should do next and the security situation being what it is you were not going to worry about taking a guy who has got some [drugs] all the way back to see the prosecutor.' 110 Cases involving higher profile suspects, however, demonstrated greater compliance with the provisions of the Law. On or about February 2010, for example, a policeman arrested by the CNPA in Helmand in connection with a trafficking operation was successfully transferred to the CJTF in Kabul. ${ }^{111}$

In fact, by $201085 \%$ of cases received by the CJTF related to offences committed in provincial areas, ${ }^{112}$ so there is evidence to suggest that the authorities were overcoming logistical and security problems to comply with article 37. However, it is estimated that in approximately $30 \%$ of all cases presented to the CNT no defendants were produced. ${ }^{113}$ In these instances drugs were found by the police, but they made no arrests or, alternatively, the police made legitimate seizures, but maintained that the suspects escaped. These alarming statistics support an analysis that compliance with the provisions of the CNL was distorted by endemic police corruption. According to a UK prosecution casework adviser interviewed in 2009, the police were known to be complicit in profiting from the seizure of drugs in the course of their duties. ${ }^{114}$ In 2009 the CNT convicted the head of the Highway Police for assisting a drugs trafficker when he was found to have ordered his men to escort a drugs dealer. ${ }^{115}$ In some instances police officers would stop and search vehicles, locate and seize drugs in the course of their duties and then divide the drugs haul amongst themselves and the drug traffickers before allowing the traffickers to move on. Alternatively, they would accept a bribe to release a suspect. According to a CNT judge, 'far too often, only the small fish were arrested and the big fish escape... often the police would let people go if they were paid enough money.' ${ }^{116}$ In other instances police officers

110 Ibid.

111 Interview, supra note 74.

112 Interviews, supra notes 74 and 80.

113 Interview, supra note 74.

114 Ibid.

115 CJTF Judge, supra note 94.

116 Ibid. 
were known to have simply disappeared following a seizure of drugs, taking the drugs with them or the cash equivalent value, having sold them back to the drug dealers from whom they were originally seized. ${ }^{117}$

To some degree the potential for police corruption was increased as a result of omissions from the transplanted content of the CNL. Article 28(3), for example, stated that vehicles seized in connection with trafficking offences could be confiscated and sold and that the sale proceeds should be deposited at the government treasury department. Yet the article failed to clarify who should be responsible for the seizure of assets and their sale or how they should account for the sale proceeds or indeed conduct a sale. This lack of prescription and clarity led to ad hoc practices being employed by law enforcement officials and enhanced their ability to profit without detection from corruption by disposing of seized assets and retaining the proceeds. ${ }^{118}$

In addition to predatory corruption by the police and law enforcement personnel, the application of the CNL was also compromised by the poor capacity of these officials and their lack of understanding of the law, particularly at the investigative phases of drug cases. Article 38 stipulated that officials conducting drugs seizures should prepare reports that included details of the type and quantity of the drug and a factual account of the seizure. Any seized drugs were to be handed over to the CNPA who gathered physical evidence of the amount and weight of the drugs and took samples that were referred for testing, following which the remaining drugs were to be destroyed. ${ }^{119}$ The scene report on drug seizures was a vital part of prosecution evidence and the samples collected samples a key feature of police investigative work.

Cases that originated in Kabul had an improved success rate because the police in Kabul handling the initial stages of the case were more likely to have received adequate training in the conduct of the investigation of drug cases than those in provincial areas. A 2008 UNODC report recorded that the CNPA in Kabul, which it described as a 'competent, albeit small, organisation,' was then conducting police investigations 'at

\footnotetext{
117 Interview, supra note 80.

118 Ibid.

119 Article 39.
} 
a level capable of assisting legal proceedings. ${ }^{\prime 20}$ Cases originating from the provinces, however, often had to be dropped because the evidential chain had been broken due to poor police practices. No witness statements would have been taken; the police would have compiled incorrectly completed or inaccurate reports of drug seizures; or samples taken from a small percentage of the haul were mislaid without any other physical evidence of the seizure having been obtained, resulting in the case being removed from CNT jurisdiction to the Provincial Courts because the amount of drugs taken from the samples was less than that required for the CNT to have jurisdiction for prosecuting the case. ${ }^{121}$ A CNT judge confirmed that 'sometimes we have to send cases back to the provincial courts because the drug amount is too small. ${ }^{122}$ It was the experience of the same judge that 'the prosecutors were good at applying the law, but still need to try to investigate the case further. Sometimes pressure is put upon prosecutors to continue with bad cases because a senior person does not like the accused. The police do not send proper crime scene reports or information on the destruction of the drugs as according to the law. The police were very ignorant and lazy and do not care or obeying the provisions of the law.'123 In some instances also the CNPA failed to destroy seized drugs after samples had been taken, in contravention of article 39, possibly as a result of insufficient funds to organise a drugs burn, but more likely owing to police corruption. ${ }^{124}$

Just as the poor capacity of the police, including the CNPA, could be said to have been hampering the successful application of the CNL an issue highlighted by UNODC in a 2008 report when it described the CNPA in general as 'not yet a competent and independent police agency $^{\prime 125}$ - the same accusation could be levelled at the criminal defence

${ }^{120}$ UNODC, Thematic Evaluation of the Technical Assistance Provided To Afghanistan By The United Nations Office On Drugs And Crime, volume 3, 2008, Law Enforcement Programme, available at www.unodc.org/documents/evaluation/2007-afghanistan.pdf [last accessed 13 March 2019].

${ }^{121}$ Interview, supra note 44.

122 CJTF Judge, supra note 94.

123 Ibid.

${ }^{124}$ Interview, supra note 80.

125 UNODC, supra note 120 , at 12. 
service. The CJTF in Kabul was reasonably well supported by capable defence lawyers approved by the Supreme Court and who received mentoring assistance. ${ }^{126}$ Judges presiding over cases in the CNT in Kabul were known to be very thorough in checking whether someone was represented and they would stop a case to allow representation to be obtained if it was requested. ${ }^{127}$ In an effort to ensure availability of defence representation some NGO's based in Kabul provided defence lawyers, operating a system similar to a duty solicitor referral scheme, so that there was a defence counsel on duty each night who could dispense advice and offer to represent a defendant charged with a CNL offence. The CJTF also endeavoured to make a telephone available to suspects when they were brought into custody in Kabul in order that they could call a defence lawyer. ${ }^{128}$ However, the extent to which this service was available, particularly during the night, was questionable. ${ }^{129}$

Because of these practices it was likely to be the case that there were more defence lawyers available to represent defendants involved in drugs cases under the jurisdiction of the CNT than there were available to suspects in other criminal offences outside CNT jurisdiction, a contention confirmed by a senior prosecution adviser in 2008: 'you would probably see more defence lawyers in the drugs cases than you would elsewhere.'130 Nevertheless, in spite of these efforts, approximately $30 \%$ of cases listed for hearing at the CNT were adjourned because defence lawyers failed to attend in order to represent their clients, contributing to a chronic backlog of cases and lengthening the period of time that defendants remained in prison awaiting trial. ${ }^{131}$ This backlog was often exacerbated by the prison department in Kabul neglecting to produce defendants for hearing, the net result of which was that only about one third of listed cases at the Tribunals in Kabul proceeded to hearing by 2010.

The delays to proceedings caused by the unavailability of defence practitioners, or indeed by the failure of the prison service to produce

\footnotetext{
${ }^{126}$ Interview, supra note 44.

${ }^{127}$ Ibid. and interview, supra note 80.

${ }^{128}$ Interview, supra note 44.

129 Ibid.

130 Ibid.

${ }^{131}$ Interview, supra note 80.
} 
parties for trial, resulted in worrying breaches of fundamental rights enshrined in international law to which Afghanistan is a signatory. ${ }^{132}$ Such delays to the trial process also ran contrary to Islamic law, which acknowledges the right of an accused to a trial without undue delay. ${ }^{133}$

\section{B. The Extent to Which the Legislation WAs Considered MeANingful and Appropriate}

The established legal order in terms of counter-narcotics criminal justice in Afghanistan has been influenced by an eclectic mix of customary practices, and religious and positive state law. As a consequence of the historically tenuous reach of the Afghan state, religious and customary practices were more influential than state legislation in shaping this order and local attitudes towards drugs. Therefore, the extent to which the provisions of the CNL were compatible with customary and religious approaches towards narcotics was significant in determining its potential for being welcomed as meaningful and appropriate by the local, or indeed the legal, population.

Customary and religious practices appear to be characterised by an ambivalent mixture of prohibition and toleration. According to MacDonald 'both opium and hashish were generally tolerated by Afghans, but the attitudes towards them were not written down in any way. There is quite a liberal attitude towards it. ${ }^{134}$ In some northern provinces opium use was considered to be an integral aspect of social existence and an acceptable form of medication and, indeed, child-care. ${ }^{135}$ According to Lau, at the customary level 'the use of drugs is strongly condemned, but no one has the right to take steps against, or even question, a person

${ }^{132}$ ICCPR, article 9(3) provides that an accused should be entitled to a trial within a reasonable period of time; article 14(3) asserts that criminal trials should be held without undue delay.

${ }^{133}$ Max Planck Manual on Fair Trial Standards, 2006, p. 76, available at www.mpil. de/shared/data/pdf/mpil_fair_trial_3rd_edition_engl.pdf [last accessed 19.03.2019].

${ }^{134}$ Interview, International Drugs and Development Adviser.

135 UNODC, supra note 91 at p. 68. 
accused of using drugs. ${ }^{\prime 136}$ Under Islamic principles opium cultivation has been haram (forbidden) while also subject to an agricultural tax (ushur) imposed by mullahs, allowing for interpretation by farmers as religious toleration. ${ }^{137}$

It is noticeable that the limitations that the CNL placed on judicial decision-making as regards sentencing were similar to the simplified rules for sentencing for Shari'a hudud offences, which were prescriptive and allow no discretion concerning punishment for an offence, provided that strict evidential requirements have been fulfilled. To that extent there was some degree of compatibility between the CNL and Shari' $a$. Nevertheless, the CNL's lack of tolerance towards drug cultivation, use, production, and trafficking, together with its strong emphasis on punishment as opposed to rehabilitation, were generally incompatible with customary and religious attitudes towards narcotics, which continued to influence approximately $80 \%$ of the population. Therefore, the CNL was unlikely to be considered meaningful and appropriate by the vast majority of the population who continued to refer to Islamic and customary practices rather than those imposed by the state.

According to a CNTF Judge, however, the procedures and practices laid down by the state and embodied in the CNL were much more appropriate for combating drug crime in Afghanistan than those prescribed by the country's other legal traditions. This Judge asserted that 'there is little dispute amongst the law enforcers that the only way to deal with the evil of drugs is through the laws. We need laws that people can understand to fight against the scourge of drugs. If the rule of law means everything, then the laws must be written down and [be] able to be understood by anyone who looks them up.' ${ }^{138}$ This suggests that there was a clear understanding amongst those concerned with enforcing state law that positive laws such as the $2005 \mathrm{CNL}$ were the most appropriate and meaningful method by which the State could seek to combat the drugs

${ }^{136}$ M. Lau, Afghanistan's Legal System and its Compatibility with International Human Rights Standards, International Commission of Jurists, 2002, p.17, available at www.icj. org/IMG/pdf/doc-51.pdf [last accessed 15.03.2019].

137 UNODCCP, Global Illicit Drug Trends 2001, p.33, available at www.unodc.org/ pdf/report_2001-06-26_1/report_2001-06-26_1.pdf [last accessed 15.03.2019].

${ }^{138}$ CJTF Judge, supra note 94. 
industry. Indeed, they were more appropriate than reliance on customary and religious rituals and norms. According to the same Judge, 'If there is a use for traditional justice, it should not be in narcotics because many think of drugs as a problem for foreigners. They would also be subject to pressure and bribery and make decisions based on what they know of the family. ${ }^{\prime 39}$ Furthermore, this Judge was clear that in his view drug crime 'should not be left in the hands of ignorant shurahs who make up their minds based on how they like the family of the people on trial.' 140 He also regarded the ability to punish offenders that the law provided as a much more meaningful and appropriate means of combating drug crime in Afghanistan than the toleration and reconciliation allowed for in customary practices, commenting that 'the Pashtunwali concentrates on reconciliation more than punishment which would not be appropriate for drugs.' ${ }^{141}$

While it is probable that there is a consensus amongst law enforcement personnel that state law is more appropriate and meaningful for combating Afghanistan's drug economy than the rules and norms provided by the country's other legal traditions, the question remains whether the transplanted content of the CNL was compatible with the established legal order as regards state law. This would impact on the extent to which it was likely, as a transplanted law, to be meaningful and appropriate to the practitioners applying it.

Some of the new measures the CNL transplant instigated certainly represented diversions from counter-narcotics legislative norms. Its provisions for search, seizure, and covert surveillance and its referral of more serious drug trafficking offences to the CNT's in Kabul, for example, were new to Afghan state criminal justice. ${ }^{142}$ Nevertheless, its stipulation that investigations, prosecutions, and trials were to be conducted in accordance with the ICPC rendered it compatible with Afghanistan's formal civil law legal tradition. ${ }^{143}$ Furthermore, its objectives were broadly similar to those contained in the 2003 law, also a legal transplant, and

\footnotetext{
139 Ibid.

140 Ibid.

141 Ibid.

142 Article 34.

143 Article 35.
} 
it continued a tradition performed by Afghan state rulers, evident since the early $20^{\text {th }}$ century, of reforming state criminal justice by transplanting foreign-designed law. In addition, the CNL's fairly unforgiving sentencing structure was aligned with the 2003 law's imposition of severe sentences to punish narcotic crime. Fundamentally, however, it was consistent with the 2004 Afghan Constitution, which confirms that 'the state prevents the production and consumption of intoxicants... [and] the production and smuggling of narcotics.' 144 To a large extent then, the CNL was compatible with the established legal order as regards state law and while its modernising features may have been inconsistent with previous state approaches to counter-narcotics they met a justifiable requirement for new investigative procedures to tackle increasingly sophisticated drug crime.

This compatibility should have enhanced the extent to which it was considered meaningful and appropriate by state law enforcers. However, there is evidence that this was not the case and that this impacted on the manner in which it was being applied. The robust article 16 sentencing guidelines were regarded as problematic and inappropriate by legal personnel. According to a CJTF Judge, the unfortunate result of article 16 was that 'too many people who were arrested were at the bottom of the gangs while the big traffickers get away, leaving poor people to spend 16 years in Pol-e-Charki prison. ${ }^{\prime 45}$ The mandatory imposition of fines under the same article was also regarded as inappropriate by the judiciary. It was rare for them to be imposed, which was perhaps not surprising, given that they were largely disproportionate to the ability of offenders to pay them. ${ }^{146}$ The minimum fine that could be imposed for possession for personal use and drug trafficking under the CNL, for example, was 5,000 Afghanis, ${ }^{147}$ representing more than $30 \%$ of average annual earnings. ${ }^{148}$

144 Article 7(2).

${ }^{145}$ CJTF Judge, supra note 94.

146 Interview, supra note 74.

147 Article 16(2)(i) and article 27(1)(c).

148 Estimated at US\$425 a year. \$1 is equivalent to approximately 43 Afghanis; UNODC, Corruption in Afghanistan. Bribery as reported by the Victims, January 2010, p. 4, available at www.unodc.org/.../Afghanistan/Afghanistan-corruption-survey2010Eng. pdf [last accessed 15.03.2019]. 
The draconian sentencing guidelines of article 16 were not the only provisions of the CNL that practitioners struggled to find meaningful and appropriate for drugs offences. A former prosecution caseworker adviser for the CJTF observed that Judges at the CNT often relied on their own intuition instead. ${ }^{149}$ At one trial five suspects were defending charges of possession under article 16. They had been stopped with a lorry containing 50 kilos of heroin and were facing life imprisonment if found guilty. Whereas a similar case in the UK might be expected to take a number weeks or months to complete, this trial was concluded within only 40 minutes. Three of the defendant's lawyers decided not to attend court and sent their client's defences to the Court in writing. The Judges were prepared to accept this and reached a decision on the evidence available to them. ${ }^{150}$ This case was not unique. At another trial in November 2009, a panel of three Judges sentenced five people to a total of 55 years in prison following an investigation lasting more than six months, which included telephone intercepts and forensic reports, and a hearing lasting merely two hours in which they accepted only the opening statements from lawyers present and failed to allow for the cross examination of witnesses. The verdict was recorded the day after the trial without calling the Court into session. ${ }^{151}$ Ruhullah Qarizada, President of the Aghanistan Independent Bar Association in 2010, also reported unsuccessfully defending a client at the CNT who was wrongly sentenced to 16 years in prison due to mistaken identity. Qarizada 'brought 50 people from [the accused's] village, the mullah, the district governor and five members of parliament who all said he is Mahmood, not Ahmad. One policeman who arrested him said he'd heard his mother call him Ahmad, so the Judge gave him 16 years in prison.' ${ }^{152}$

An Afghan defence expert based in Kabul confirmed that the Judges at both the CNT and the provincial courts presiding over drugs cases 'do not follow the law. They do not use the CN law. They do what they

${ }^{149}$ Interview, supra note 80.
${ }^{150}$ Ibid.
${ }^{151}$ J. Starkey, Judges Convicting To Please West, Say Striking Lawyers, The Times, 28 February 2010.

152 Ibid. 
want. ${ }^{\prime 153}$ The same authority claimed that 'the judges just ignore the evidence, they don't care...for example, when they arrest a person and find 2 kilos of drugs at the time of the search of his home, they sentence him on the basis that they found 10 kilos of drugs at his home. They do not consider the evidence. ${ }^{\prime 154}$ In a further interview this expert stated that 'there [was] a case involving 50 kilos of sugar found at a house. A man is arrested and sentenced to 16 years imprisonment on the basis that it is 50 kilos of heroin. ${ }^{155}$ Judges were deliberately ignoring the provisions set down in the CNL 2005. According to an international expert, the CNL was 'counter cultural' for practitioners and, in relation to its application by judges and prosecutors, 'you were trying to introduce [the $2005 \mathrm{CNL}$ ] but they just don't understand it, as it goes against everything that they were used to.'156

Judges, it would appear, were not properly applying the law because they did not consider it to be culturally meaningful and appropriate. This was also the case with respect to police and prosecutors. Part of the rationale behind establishing the CJTF was that it would enhance the prosecution of drug cases by bringing the police and prosecution together so that they could work as an effective team to investigate and prosecute cases properly. In practice, however, fostering a working relationship between the prosecutors and the police proved to be difficult. ${ }^{157}$ The police may conduct initial investigations and refer cases to prosecutors within the time limits set down by the law, but they would often do this irrespective of the state of the evidence that had been gathered and compliance with the provisions of the CNL. According to a prosecution casework adviser interviewed in 2008, the 'police do not understand that they need to give a caution,' which he surmised is due to a 'cultural' lack of an acceptance that it should be required. ${ }^{158}$ Moreover, a 2008 UNODC report noted that 'many CNPA officers do not fully understand the concept of intelligence gathering, accurate recording and analysis,

\footnotetext{
${ }^{153}$ Interview, senior Afghan defence lawyer.

${ }^{154}$ Ibid.

155 Interview, senior Afghan defence lawyer.

156 Interview, supra note 46.

157 Interview, supra note 44.

158 Ibid.
} 
and referral to other units and agencies. ${ }^{\prime 159}$ It concluded that the proper recording and gathering of intelligence by law enforcement personnel is often frustrated 'due to cultural reasons.'160

An international prosecution mentor interviewed in 2008 confirmed that if the prosecution discovered a break in the evidential chain which may be fatal to the prospects of a successful prosecution, they were often reluctant to refer the matter back to the police for further investigation. ${ }^{161} \mathrm{At}$ the same time, the police were unenthusiastic about receiving instructions from prosecutors about how to conduct their investigations. According to a former member of the UK Drugs Team, 'it [was] very hard to break down the barrier between the two. There [was] a constant... cultural conflict...where the police and prosecutors work together.' ${ }^{162}$ Another international expert noted that at the CJTF 'the police and prosecutors just do not get on at all and the prosecutors, once they get [a case], don't actually refer it back to the police.' 163 He concluded that 'so few cases were actually investigated properly [because] it is going against all sorts of cultural norms for the Afghans. ${ }^{\prime 164}$ The same expert noted that 'from the judges down, they just don't understand what the law is there for and how to use it. It is contrary to everything they have done in the past.'165

In the light of these findings it is probably fair to say that the extent to which the CNL was likely to be considered meaningful and appropriate to Afghans was directly associated with the reach of the formal system of justice. While the reach of the formal system remains limited to $10-15 \%$ of the population, only the same percentage of the population were likely to potentially regard the CNL as meaningful and appropriate for dealing with drug use, cultivation, production, and trafficking in Afghanistan. For the majority of the population for whom Islamic and customary approaches had more resonance than legislative rules imposed by the state, the CNL had, therefore, limited meaning. Indeed, an international

\footnotetext{
159 UNODC, supra note 120 at 12.

160 Ibid.

161 Interview, supra note 44.

162 Ibid.

163 Interview, supra note 46.

164 Ibid.

165 Ibid.
} 
expert confirmed in 2008 that 'nationally, it is not known by many people.' 166 The punitive nature of the CNL, furthermore, should also be regarded as incompatible with customary and religious tolerance towards narcotics, and their emphasis on reconciliation and rehabilitation. This may have adversely influenced the potential for the CNL to be considered meaningful and appropriate to the sections of the population who referred to Islamic and customary practices.

Whilst acknowledging these problems, the CNL was largely consistent with the established legal order represented by formal state law. While this augured well for its potential for being considered meaningful and appropriate by Afghan legal practitioners and law enforcement agents, evidence suggests that on the contrary some police officers, prosecutors, defence lawyers, and judges struggled to apply the transplanted content of the law, because it was 'counter cultural', removed from their experience of the established legal order and the norms and rituals which they might associate with counter-narcotic justice. ${ }^{167}$ According to an international Drugs and Development Adviser, the CNL '[went] against their [legal actors'] understanding of what is important and meaningful.' ${ }^{168}$ This is likely to have impaired its application and the potential for its acceptance as a legal transplant.

\section{The Motivations for TRansplantation AND THEIR IMPACT ON RECEPTION}

There were significant international as well as domestic motivations for a new CNL in 2005. At the international level, the vast majority of opium being produced in Afghanistan was for consumption abroad at various

166 Ibid.

167 According to Roder 'even though not explicitly, the justice institutions do exclude the prosecution of illicit drug production from their responsibility. There is a general consent that poppy cultivation is necessary for the economic survival of the provincial population and that any form of ...prosecution would endanger their existence;' T. J. Roder, Provincial Needs Assessment: Criminal Justice in Uruzgan Province, 2010, p.11, available at www.mpil.de/shared/data/pdf/pna_uruzgan_final_1.pdf [last accessed 19.03.2019].

168 Ibid. 
American, European and Asian destinations for which the return of an opium-driven economy in the aftermath of the international intervention in 2001 had serious negative ramifications. Afghan poppy fields became the fastest-growing source of heroin in the United States. ${ }^{169}$ Heroinrelated death rates in Los Angeles increased by 75\% between 2002 and 2005 and the overall US market for Afghan heroin doubled between 2001 and 2004. ${ }^{170}$ Beyond the US, in Europe and Asia, according to the 2005 World Drug Report, opiates 'continued to be the main problem drug, accounting for $62 \%$ of all treatment demand. ${ }^{\prime 171}$ In addition, the UK was under pressure to produce and implement a cohesive counter-narcotics strategy to honour its lead nation role and to add justification to its continued military involvement in Afghanistan since 2001, the result of national self-interest in disrupting at source the importation of heroin into Britain. ${ }^{172}$ The UK and her international partners were keen to prompt the Afghan government to adopt a more proactive counter-narcotic strategy, which was now embodied in the Implementation Plan, the creation of the CJTF and the new centralised courts, and which would be complemented by a new CNL. According to the former Head of the Rule of Law team at the British Embassy in Kabul in 2005:

'the decision that is made in consultation with the Afghan government is that we would have a Central Tribunal and a Task Force to look at the drugs issue because in great parts of the country the government [did] not have reach. It did not have a formal justice system that is working. There were some areas where there were no judges and no prosecutors and because of the scale of the drugs problem it is felt necessary to have some sort of centralised control over the Afghan side with international mentors. ${ }^{173}$

On the domestic front, there was a political awareness at government level that new initiatives and procedures would be required to combat

169 Ibid.

${ }^{170}$ G. Therolf, Afghan Heroin's Surge Poses Danger in US, Los Angeles Times, 26 December 2006.

171 UNODC, supra note 38 at 5.

172 Tony Blair confirmed in 2001 that it is in the UK's interests to engage militarily in Afghanistan because it is the source of $90 \%$ of UK's heroin; see P. Oborne, Afghanistan: Here's One We Invaded Earlier, Channel 4, 31 May 2004.

${ }^{173}$ Interview, supra note 44. 
drug crime and opium production. ${ }^{174}$ Without these measures, opium cultivation, production and trafficking would remain a threat to the security of the country, represented by warlords, extremist terrorist groups, and the emerging Taliban, all of whom were continuing to profit from the industry. At the government level also, there would certainly have been an awareness of the need to co-operate with international requirements for imposing new counter-narcotics measures in order to ensure continued financial support and the prospect of new funding pledges. According to an international expert interviewed for this research 'for central institutions, what [was] more relevant [was] that this [the CNL] granted new pledges and other financial commitments...this is what does really matter. ${ }^{175}$

President Karzai, who passed the CNL by decree without parliamentary approval, may well have been motivated to introduce a new CNL primarily to appease and maintain working relations with important international sponsors of the new administration, and particularly the US and the UK. The dependence on international assistance is a common occurrence for new governments installed in states seeking to emerge from conflict and intent on enhancing the rule of law. However, this dependence can create an unequal working relationship between local officials and international actors which can translate into international control of legislative reform, conducted by legal transplantation. This appears to have been the case with regard to the CNL. It was drafted principally by officials from the UK and the US who, in a similar vein to criminal justice reform programmes in East Timor ${ }^{176}$ and Kosovo ${ }^{177}$, chose to rely on legal transplantation as a means for promoting legal change.

174 In November 2004 President Karzai confirmed that tackling the drug trade would be a key priority for the new government. To underline this intent, at his election victory speech on 4 November 2004 he called on Afghans to join him on a 'jihad' against the opium trade.

175 Interview, Italian Legal Consultant, 17.11.2008.

176 The United Nations Transitional Administration in East Timor (UNTAET) passed 71 regulations during its four-year mandate, during which it undertook a comprehensive amendment of East Timor's criminal procedure.

177 The United Nations Assistance Mission in Kosovo (UNMIK) passed 257 regulations between 1999 and 2004, many of which were designed to reform Kosovo's criminal justice system. 
Developing the CNL by legal transplantation would mean that it could be drafted quickly, which was considered a priority by the international donors assisting the Afghan government in counter narcotic policy-making. The former Head of the UK Rule of Law team confirmed that 'in order to deal with the drugs problem, which [was] an immediate threat to security and stability in the country, something needed to be fasttracked in order to allow that to happen. So essentially a small criminal justice system [was] set up to deal with counter-narcotics. ${ }^{178}$

It seems clear that modernisation played its part in motivating change by transplantation. There was a consensus amongst international agencies by 2004 that the 2003 law required revision. ${ }^{179}$ According to one report, although the 2003 law had been 'a major step forward compared to previous legislation...it did not address the 'working needs' of drug law enforcement officials. ${ }^{\prime 180}$ It was intended that these needs would be met by modern investigative and counter surveillance techniques provided for in the 2005 law and designed to complement the new counter-narcotics strategy, enabling end-to-end centralised control of more serious drug trafficking cases. According to the former head of the UK Rule of Law team:

'Life had moved on and Afghan law had not. Under the formal system what they were doing was going back to their Criminal Procedure Code of the mid-to-early 1970's. The world had obviously moved on tremendously since then. So there were some elements of drug law enforcement and criminal justice that we know about in the outside world that (a) [the Afghans] had not experienced and (b) that had not been around when those laws were passed. If you go back to the Afghan law it simply did not have the tools in it to deal with the sophistication of the crime that now existed'. ${ }^{181}$

By modernising the counter-narcotics law, Afghanistan's international partners sought to improve the country's criminal law framework and enhance the potential for establishing the rule of law. They were also, however, motivated by the concerns of their own domestic and foreign policies, which were intent on key issues such as promoting stabilisation

\footnotetext{
178 Interview, supra note 44.

179 UNAMA, supra note 31 at p. 7.

${ }^{180}$ NDCS, supra note 22 at p. 45.

181 Interview, supra note 44.
} 
in central Asia, developing counter-terrorism strategies, and reducing the domestic importation of Afghan opiates. In seeking to meet both Afghan criminal justice and their own domestic needs, the international drafters of the CNL engaged in a policy of modernisation by transplantation. However, transplanting foreign legal concepts resulted in a means of reform perhaps more concerned with conformity to international standards than with Afghanistan's dominant legal traditions. According to an International Drugs and Development adviser, 'the big thing from the international[s] is that...they want something sophisticated that mirrors their own system and covers all aspects and...meets international conventions requirements. However, [the CNL did] not really show appreciation of Afghan society and tribal norms. ${ }^{\prime 182}$ As noted earlier, this was a form of modernisation that, although compatible with Afghan state law, was largely incompatible with customary and religious approaches to counter-narcotics and therefore unlikely to appeal to the majority of the nation. This had implications for the acceptance of the CNL and its potential for achieving its objectives. It is difficult to assess whether the CNL promoted local antipathy towards the Afghan government, but there is evidence that it was disliked and that its objectives were viewed by certain sections of the Afghan population as disconnected from the national consciousness. An international expert confirmed in 2010 that the Afghan 'parliament does not like the 2005 law because it is brought in by Presidential decree ${ }^{\prime 183}$ and a CNT Judge advised for this research that 'many think of drugs as a problem for foreigners' ${ }^{184}$ rather than for Afghans. Supporting this analysis, a former head of the UK Rule of Law team based in Kabul between 2005 and 2007 claimed that the 'impression from the Afghan side [was] that it is foreign-imposed and they would probably say that it [was] more US-imposed, perhaps because the US were more involved at the end point [of the drafting]. They feel that it [was] more international than Afghan.' ${ }^{185}$

Reforms such as the CNL, motivated by modernisation and instigated by means of transplantation do not come with a guarantee of success.

\footnotetext{
182 email correspondence, international Drugs and Development adviser.

183 Interview, supra note 74.

${ }^{184}$ CJTF Judge, supra note 94.

185 Interview, supra note 53.
} 
With the armies of the countries who helped to draft the law still present in the country and engaged in supervising the enforcement of the law, it may also be regarded with scepticism as an externally-designed law intent on serving foreign interests, undermining its potential for being properly applied and accepted. Modernising legal reform lacking the endorsement of nationals is more prone to lack in legitimacy and will struggle to be accepted by the local population. Furthermore, historical analysis of criminal justice reform in Afghanistan reveals that attempts by previous Afghan rulers to impose modernised state justice mechanisms on the rural population have not only failed, but have also provoked considerable resentment towards the Afghan state. ${ }^{186}$

\section{The Extent to Which the Counter Narcotics LaW 2006 AchieVed its Objectives}

The CNL contained seven stated objectives. It was designed to prevent the cultivation of specified illicit narcotic drugs ${ }^{187}$ and prescribe penalties for, amongst other activities, their illegal cultivation, production, and trafficking. ${ }^{188}$ It also sought to regulate and control the production and processing of narcotic drugs, psychotropic substances and chemical precursors, ${ }^{189}$ and to coordinate and monitor the government's counternarcotics activities, policies, and programmes. ${ }^{190}$ In addition, the CNL aimed to encourage the cultivation of licit crops, ${ }^{191}$ establish treatment, rehabilitation and harm reduction services, ${ }^{192}$ and attract national and international assistance programmes in the fight against illicit narcotic cultivation, production and trafficking. ${ }^{193}$

${ }^{186}$ M. Tondini, Statebuilding and Justice Reform: Post-Conflict Reconstruction in Afghanistan, Routledge 2010.

187 article 2(1).

188 article 2(3).

189 article 2(2).

190 article 2(4).

191 article 2(5).

192 article 2(6).

193 article 2(7). 
The basis of the law, affirmed in article 1, and arguably its main objective, was to provide the Afghan state with a legal framework for preventing the cultivation and trafficking of illicit narcotic drugs, particularly opium poppy. During the period of its enforcement, however, drug production, cultivation, and trafficking continued to be conducted on an enormous scale and those profiting from the trade were able to operate with apparent impunity. The annual levels of cultivation and production of opium poppy in each of the years since the law was passed in 2005 up to 2008 exceeded those of any of the previous years up to 1994. ${ }^{194}$ Indeed, the area cultivated and the amount of opium produced in the three years from 2006 to 2008 was more than that produced and cultivated during the preceding 6-year period from 2000 to $2006 .{ }^{195} \mathrm{In}$ $2007,193,000$ hectares of opium poppy were cultivated, more than at any other time in the recorded history of poppy cultivation and production in Afghanistan. ${ }^{196}$ At the time of the law's introduction, Afghanistan accounted for $89 \%$ of global opium production. By 2008 it had increased to $96 \%{ }^{197}$ and it has remained at more than $90 \%$ between 2006 and $2010 .{ }^{198}$

There were, nevertheless, some notable successes in reducing opium cultivation. Nangarhar, the second highest opium-producing province in 2007, was declared to be poppy free by 2008. A 2010 report noted a $33 \%$ drop in cultivation over the previous 2 years. ${ }^{199}$ Furthermore, the number of opium-free provinces in Afghanistan had increased from 6 in 2006 to 25 by $2010 .^{200}$

It is difficult to fully assess the effect of the CNL on opium cultivation and whether production might not have increased more without it or,

194 UNODC, World Drug Report 2009, p. 34, available at www.unodc.org/unodc/en/ data-and-analysis/WDR-2009.html [last accessed 19.03.2019].

195 Ibid.

196 UNODC, Afghanistan Opium Survey 2008, p. vii, available at www.unodc.org/ documents/publications/Afghanistan_Opium_Survey_2008.pdf [last accessed 19.03.2019].

197 UNODC, supra note 194 at 33-34.

198 UNODC, World Drug Report 2010, p. 42, available at www.unodc.org/documents/ wdr/WDR_2010/World_Drug_Report_2010_lo-res.pdf [last accessed 19.03.2019].

199 UNODC, Afghanistan Opium Survey 2010. Winter Rapid Assessment, February 2010, p.1, available at www.unodc.org/documents/frontpage/Afghanistan_Opium_ Survey_2010_Final.pdf [last accessed 15 March 2019].

200 Ibid. 
indeed, whether any of the inroads into poppy cultivation owed anything to its application and enforcement. A 2008 UNODC report suggested that poppy reduction was the result of 'good local leadership and bad weather,' 201 asserting that the impact of law enforcement and criminal justice initiatives on the reduction of poppy cultivation in 2008 had been negligible compared to that of religious and customary influences. It concluded that 'religious leaders, elders, and shura deserve credit for becoming increasingly effective in convincing farmers not to grow opium, not least because it is against Islam,' and that counter-narcotic measures to build integrity and justice, and ensure 'good governance, efficient administration and honest judiciary...have yet to gain momentum.' ${ }^{202}$ A 2010 report maintained that market forces played the principal role in deterring farmers from opium cultivation and that in the south-western regions, where most of the country's opium was grown, low prices and low yields were the main reasons for farmers refraining from growing opium. ${ }^{203}$ On the other hand, the same report noted that in the northwestern provinces $61 \%$ of farmers refrained from growing opium in 2010 'because it is illegal, ${ }^{204}$ so there was some indication that the legal framework established by the 2005 CNL was becoming increasingly recognised among the rural population in more stable provinces. ${ }^{205}$ There is, then, some evidence of the law achieving its objective of preventing poppy cultivation, although this was largely influenced by varying degrees of regional security.

There is also evidence that the legal framework set up as a result of the $2005 \mathrm{CNL}$ achieved some creditable success in preventing drug trafficking. Drug traffickers were successfully arrested, prosecuted by the CJTF, and convicted at the central courts. Initially, the CNT got off to a slow start when it was established. By April 2007 the Primary Court had received 42 cases, but had only reached verdicts in 2 of them, and

201 UNODC, supra note 196 at p. vii.

202 Ibid.

203 Ibid. at p. 1.

204 Ibid.

205 D. Mansfield, Sustaining the Decline?:Understanding the Changes in Opium Poppy Cultivation in the 2008/09 Growing Season, May 2009, p. 2, available at www.fco.gov.uk/ resources/en/pdf/pdf21/drivers-report-0809 [last accessed 15.03.2019]. 
the Appeal Court had received 60 cases, but had failed to reach any decisions at all. ${ }^{206}$ However, there followed a period of rapid increase in case turnover and conviction, and for the 3-years between May 2005 and June 2008 the CJTF prosecuted 1,486 cases, resulting in the conviction of 587 defendants, 181 acquittals and the referral of 46 people to treatment centres. In the same period the CJTF reviewed 890 cases from other courts in Afghanistan, resulting in the conviction of a further 968 individuals. By June 2008 a total of 1,555 people had been convicted at the CNT for drug-related offences. ${ }^{207}$ As a result of these encouraging statistics the Afghan Attorney-General announced in December 2008 that the 'CJTF has had an excellent and successful performance towards disrupting the narcotics trade and bringing drug traffickers to justice. ${ }^{208}$

In 2009, 278 cases were heard at the Primary Court and 299 defendants were convicted, representing an 89\% conviction rate. ${ }^{209}$ Between March 2009 and March 2010, the CJTF convicted a further 599 drug-traffickers. ${ }^{210}$ A further 155 convictions were secured in the first quarter of the Islamic year 1389 (March 2010-March 2011). ${ }^{211}$ By March 2011 the conviction rate was $96 \% .^{212}$

Undoubtedly, then, some progress was made with regard to the CNL meeting its objective of preventing drug trafficking. Nevertheless, the positive achievements of the CJTF were tempered by the fact that the vast majority of the cases that it processed concerned couriers at the bottom end of the trafficking industry rather than the controllers of the drug trafficking networks who were the priority targets. ${ }^{213}$ The first key priority of the government's 2006 NDCS was to disrupt 'the trafficking networks' by 'targeting traffickers and their backers. ${ }^{214}$ There were some

${ }^{206}$ UNAMA, supra note 31 at p. 33.

207 Agahee, Afghanistan is Committed to Bringing Drug-traffickers to Justice, Criminal Justice Task Force Communications Directorate, 2008, at p. 22.

208 Ibid. at p. 32.

${ }^{209}$ CJTF statistics, available at www.cjtf.gov.af [last accessed 15.03.2019].

210 Ibid.

211 Ibid.

${ }^{212}$ Interview, senior member of Rule of Law team, ADIDU, London.

${ }^{213}$ Interview, supra note 43. According to his expert the CJTF is concerned 'largely with low level cases and there is not much movement up the chain from that.'

${ }^{214}$ NDCS, supra note 22 at p. 18. 
occasional successes. According to the CJTF in 2009 'the number of cases involving middle or high-value targets ha[d] increased by over 300 percent in the last year to reach 10 percent of the total number of cases. ${ }^{215}$ Between March 2008 and February 2009 the CJTF successfully convicted 26 medium-value targets, classified as those people directly above the couriers in drug networks. ${ }^{216}$ This compared with 13 convictions of similar offenders in the preceding 12-month period. ${ }^{217}$ Furthermore, Haji Abdullah, thought to be in charge of the country's third biggest drugs network, was convicted in 2009 following the submission of telephone intercept evidence, permitted under the CNL. ${ }^{218}$ Another leading figure in the drugs trade in Afghanistan, Haji Rashid, had his conviction upheld in the Appeal Court in 2010 and received a 20-year sentence and a US\$10 million fine. ${ }^{219}$ According to the CJTF these cases demonstrated that, equipped with the legal tools provided by the CNL, 'the Afghan government can now disrupt major networks.' ${ }^{220}$ Progress had been made, but it was slow. Abdullah and Rashid represented the first 'high value' targets successfully prosecuted under the CNL since its enactment six years previously. ${ }^{221}$

In spite of these successes, the percentage of cases successfully prosecuted concerning medium to high-level targets was, in reality, minimal, given that there were estimated to be between 800-900 mid and high-level traffickers in Afghanistan. ${ }^{222}$ Furthermore, there was also some concern amongst international observers that the number of cases that the CJTF received had plateaued by 2010. By then it was processing

${ }^{215}$ UNODC, Addiction, Crime and Insurgency. The Transnational Threat of Afghan Opium, 2009, p.140, available at www.unodc.org/docs/data-and-analysis/Afghanistan/ Afghan_Opium_Trade_2009_web.pdf [last accessed 15.03.2019]

${ }^{216}$ Interview, supra note 80.

217 Ibid.

${ }^{218}$ J. Boone, Afghan Opium Baron Gets 20 Years as UK Anti-Narcotics Strategy Pays Off, The Guardian 11.08.2009.

${ }^{219}$ Interview, senior Rule of Law officer, ADIDU. She could not comment on the nature of the case on the basis that it was sub judice.

220 Boone, supra note 218.

221 Ibid.

222 UNODC, supra note 215 at p. 105. 
and prosecuting on average approximately 30 cases a month. ${ }^{223}$ In the 10-month period from March 2008 to January 2009, the CJTF dealt with 334 cases and a total of 370 defendants. ${ }^{224}$ Between March 2009 and March 2010 the CJTF received 395 cases. ${ }^{225}$ Given the size of the opium economy in Afghanistan - estimated to be worth $\$ 2.4$ billion a year ${ }^{226}$ - it would not be unreasonable to have expected the CJTF to receive and prosecute substantially more drug cases falling under the jurisdiction of the CNL and, indeed, more cases involving higher-end drug traffickers. In fact, a 2011 UNODC report concluded, 'the impact [of the CNL] on major drug traffickers and organised criminal groups has been limited and the seizures have been small compared with the vast amount of drugs produced.' 227

The CNL also included an objective to establish detoxification, treatment, rehabilitation, and harm reduction services for drug dependent individuals. ${ }^{228}$ In conjunction with this, article 27 provided that addicts could be referred to detoxification or drug treatment centres following medical examination. While the intent of the CNL was to treat drug addiction and encourage the reintegration of drug users back into society, the prospect of successful rehabilitation following treatment was unlikely given a lack of social reintegration, aftercare measures and education programmes, which were not required to be provided by the law. ${ }^{229}$

There were estimated to be more than a million drug users in 2008. ${ }^{230}$ Afghans were more vulnerable to becoming addicts because of the continuing conflict following 25 years of war, social and economic disruption, and resulting chronic mental health problems of its population. ${ }^{231}$ It is arguable, ironically, that the CNL actually contributed to Afghanistan's drug addiction crisis, as the majority of the country's

${ }^{223}$ Interview, supra note 80.

${ }^{224}$ Statistics available at www.cjtf.gov.af/en/pr/18-march-12-2009.html [last accessed 19.03.2019].

225 Supra note 209.

226 UNODC, supra note 198 at p. 42.

227 UNODC, supra note 120 at p. 12.

${ }^{228}$ Article 1(6).

${ }^{229}$ UNODC, supra note 91 at p. 25.

${ }^{230}$ Ibid. at p. 68.

231 Ibid. at p. 58. 
addicts started their drug habits in prison and the law's tough sentencing guidelines resulted in most drug offenders being punished by imprisonment. And so, according to UNODC, 'the CNL represent[ed] a prescription to ensure an ever increasing prison population and an ever increasing number of drug addicts. ${ }^{232}$

Some progress has been made in establishing drug treatment facilities. In 2002 there were only 2 drug treatment, rehabilitation, and harm reduction services in the country. ${ }^{233}$ By 2009 this had increased to 39 , offering 495 residential places. ${ }^{234}$ The net result, however, was that less than $0.25 \%$ of Afghanistan's drug users could be treated each year given the available treatment amenities. ${ }^{235}$ There was, then, a huge gap between treatment demand and provision, and the objectives of the CNL to ensure the provision of appropriate treatment services, the reintegration of drug users back into society, and the reduction of drug dependency were not met.

The CNL also aimed to prevent the trafficking of chemical precursors used in the refinement of morphine to heroin, ${ }^{236}$ and to attract international cooperation and assistance to combat precursors and narcotic trafficking. ${ }^{237}$ These objectives built on commitments expressed by the international community at a conference in Paris in 2003 to share responsibility for combating opiates trafficking from Afghanistan, ${ }^{238}$ later reiterated at a follow-up conference in Moscow in June 2006. The resulting 'Moscow Declaration' led to the establishment of cross-border consultative groups designed to share counter-narcotic data and coordinate technical assistance relating to the trafficking of opiates from Afghanistan in order to enhance trafficking prevention. As part of this process a consensus was reached that more attention should be paid to preventing the

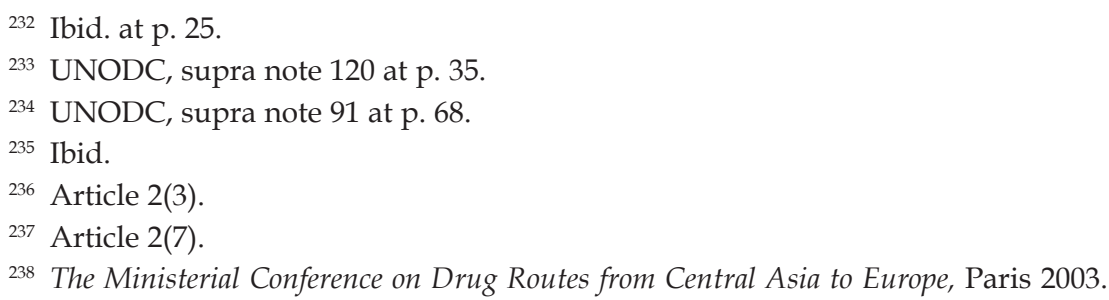
More than 50 countries and international organisations attended and agreed to work together to combat opiate drug trafficking deriving from Afghanistan. The partnership became known as the 'Paris Pact.' 
flow of chemical precursors into Afghanistan, ${ }^{239}$ as a result of which a Targeted Anti-Trafficking Regional Communication, Expertise, Training (TARCET) initiative was launched under UNODC guidance, aimed at targeting precursors used in the manufacture of heroin in Afghanistan. In addition, a UN Security Council resolution passed on 11 June 2008 called on Member States to step up their efforts to stop precursors being smuggled into the country. ${ }^{240}$

Increased cooperation between member states and also joint operations by countries within the framework of the Paris Pact and the Moscow Declaration led to successful seizures of precursors. Operation TARCET was responsible for the seizure of 47 metric tons of precursors in Afghanistan and its neighbouring countries. ${ }^{241}$ It is doubtful whether these seizures would have taken place without the international assistance resulting from the Paris and Moscow conferences. Nor is it likely that the international community would have been so forthcoming in lending assistance of this nature unless Afghanistan had a law such as the CNL 2005 criminalizing drug and chemical precursor trafficking, providing internationally approved classification and regulation of precursors and narcotic drugs and equipping enforcement agents with more modern counter-surveillance measures. To that extent, CNL 2005 had some success in meeting its objective of preventing the trafficking of precursors. ${ }^{242}$ The same might also be said in relation to its objective of attracting international cooperation and assistance. The UK alone spent $£ 290$ million between 2005 and 2008 supporting a number of counternarcotics measures ${ }^{243}$ and committed \$US20 million between 2004 and 2011 specifically for the CJTF. ${ }^{244}$

239 Moscow Declaration, Second Ministerial Conference on Drug Trafficking Routes from Afghanistan, Moscow, 26-28 June 2006, at p. 4.

240 S/Res/1817 SC/9352, 11.06.2008.

${ }^{241}$ UNODC, supra note 194 at 37.

${ }^{242}$ In the first 50 interdiction operations in $2011338 \mathrm{kgs}$ of chemical precursors were seized and 58 suspects arrested; UKFCO, January Progress Report on Afghanistan, January 2011, available at www.fco.gov.uk/en/news/latest-news/?view=PressS\&id=558520482 [last accessed 19.03.2019].

${ }^{243}$ UKFCO statistics, available at www.fco.gov.uk/en/fco-in-action/uk-in-afghanistan/ Counter-Narcotics [last accessed 19.03.2019].

${ }^{244}$ The UK pledged US\$12 million over the three-year period from 2004 to 2007; in 
These advances were not shared in relation to the CNL's objective to coordinate, monitor and evaluate the counter-narcotics activities of the Afghan government, the responsibility of the Ministry of Counter Narcotics. The Ministry consisted of a number of departments set up on thematic lines to complement the eight pillars of activity under the NDCS 2006, and six working groups were established to analyse the effect of counter-narcotic measures in relation to each pillar activity. It was, however, described by an international expert interviewed for this research as 'a huge mess.' ${ }^{245}$ Its predecessor, the Counter Narcotics Directorate, had been reviewed in 2003-2004 and it was recommended at that stage that it would be more effective in carrying out its remit of monitoring counter narcotics policy and strategy if it was reduced in size and staffed with better quality personnel with higher salaries. Rather than following this recommendation, however, the Afghan government and the UK were responsible for creating a new Ministry that employed too many people, most of whom were on small salaries and incapable of doing their jobs. ${ }^{246}$

It is also the case that there was minimal communication between the various Ministry departments, which tended to focus only on their own areas of responsibility. UNODC found counter-narcotics law enforcement in 2008 to be hindered by a 'lack of trust between the various ministries [that] hinders the sharing of information.' ${ }^{247}$ In June 2009 an international expert maintained that the problem is and still is that the various departments were too territorial and just concerned with protecting their own empires and areas of responsibility. ${ }^{248}$ In an effort to improve the capacity of the Ministry, the UK funded a $£ 12.5$ million project deploying task forces comprised of experts from the different areas with which the Ministry was supposed to be concerned. Such task forces provided technical assistance to staff involved in the various pillar activity departments. In spite of these efforts, while the Ministry

April 2007 the UK committed to funding \$US 18 million from 2007-2011 for the CJTF; UNAMA, supra note 31 at p. 33.

245 Interview, supra note 43.

246 Ibid. It employed approximately 450 staff.

${ }^{247}$ UNODC, supra note 120 at p. 12.

${ }^{248}$ Interview, supra note 43. 
remained functional, it was inefficient and viewed with some distrust by the international community. ${ }^{249}$ It did not effectively co-ordinate the government's counter narcotic activities. Nor was it capable of properly evaluating the implementation of the NDCS. In short, the Ministry failed to carry out its mandate as set out in article 52 CNL 2005. The worrying reality by 2010 was that, while Afghanistan continued to dominate world illicit opium exportation, it still possessed no competent state institution capable of evaluating its national counter-narcotics strategies, including those for legislative reform.

\section{FINDINGS AND CONCLUSION}

There were compelling reasons for the development of a counter narcotics law in 2005. New legislation could provide more appropriate techniques for investigating increasingly sophisticated drug trafficking operations and complement the government's 2005 Counter Narcotics Implementation Plan and the establishment of the CJTF and the CNT. In catering for these requirements the architects of the new law chose to transplant foreign solutions. In this regard, it is arguable that this merely conformed with historical tradition in Afghanistan. Since the beginning of the $20^{\text {th }}$ century Afghanistan's various rulers and regimes had attempted to create a functioning state criminal justice system to augment and uphold the philosophies upon which their rule was based, and to do this they undertook programmes of constitutional and legislative reform involving extensive legal transplantation. Hanafi figh was codified and transplanted into penal law, and western substantive and procedural laws with a civil law tradition were also borrowed and transplanted into new penal and procedural codes. ${ }^{250}$ Transplanted legal solutions had certainly, therefore, been historically instrumental in the development of Afghanistan's state legal system.

249 Ibid.

${ }^{250}$ For example Ammanullah's 1924 Penal Code borrowed provisions from the French Penal Code, as was the case with the 1965 Criminal Procedure Law and the 1976 Penal Code; G. H. Vafai, Afghanistan. A Country Law Study, Library of Congress, 1988. 
This justification for relying on transplantation was also supported by contemporary international recommendations for post-intervention reform advocating that post-intervention countries should be equipped with effective legal frameworks in the form of modern laws ${ }^{251}$ consistent with international human rights norms. ${ }^{252}$ Legal transplants could quickly assist in meeting these objectives.

What, however, of the central questions this paper seeks to address; namely, whether the CNL was a successful transplant and whether it was reasonable to rely on transplantation to develop the CNL, taking into consideration the evaluation of this law? Dealing with the first of these issues, the CNL can be acknowledged as having some successful attributes. It provided new investigative techniques for increasingly sophisticated trans-national drug trafficking operations, and transplantation led to the development of a new legal framework that helped to secure the conviction of medium and high-level traffickers. ${ }^{253}$ It has been complimented by a CNT Judge responsible for some of those convictions, who described it as a 'good law. ${ }^{\prime 254}$ Furthermore, its provisions met the imperative demand of compliance with international standards of human rights and due process, without which the ideal of establishing the rule of law through law enforcement in Afghanistan would be unrealisable.

In spite of these accomplishments, this analysis finds that the CNL was not a successful legal transplant. There were significant problems as regards its application, it meaningfulness, and its objectives, many of which derived from their transplanted content. It is also apparent that the motivations for developing this legislation by transplantation and the consequent process of its development combined to moderate its reception.

${ }^{251}$ United Nations, Report of the Secretary-General: The Rule of Law and Transitional Justice in Conflict and Post-Conflict Societies, U.N. Doc. 5/2004/616, 23 August 2004, para 30, available at www.daccess-dds-ny.un.org/doc/UNDOC/GEN/N04/395/29/PDF/ N0439529.pdf?OpenElement [last accessed 19.03.2019].

${ }^{252}$ Ibid. at para 6.

253 Blanchard has argued that the CNL 'clarifie[d] administrative authorities for counter narcotics policy and establishe[d] clear procedures for investigating and prosecuting major drug offences.' Supra note 23 at p. 116.

${ }^{254}$ CJTF Judge, supra note 94. 
The transplanted content of the CNL impacted on its application. It contained an inappropriately draconian sentencing regime with limited allowance for judicial discretion relative to degrees of criminal responsibility. In addition, its insistence on the referral of cases to Kabul created logistical problems that increased the potential for inconsistent application of its provisions and the arbitrary detention of defendants. Moreover, its concentration of power in institutions and in foreign-trained professionals in Kabul contributed to the promotion of Afghanistan's centre-periphery divide and antipathy towards the central administration and its reform efforts, which have historically adversely affected the reach, legitimacy, and reception of state laws.

The transplanted content of the CNL also struggled to be considered meaningful and appropriate by those responsible for applying them and the Afghan public. The government's October 2005 Justice for All strategy had called for new legislation to include counter-narcotic measures that should comply with international standards and Islamic principles, but which should also seek ways of engaging with traditional justice systems. ${ }^{255}$ Yet the CNL, passed 2 months later, provided no such negotiation between Afghanistan's legal traditions and conformed primarily to international expectations. Its punitive sentencing provisions were incompatible with the tolerance and reconciliation of customary and religious approaches to counter narcotic crime. Moreover, the referral of criminal matters to customary and Islamic justice authorities and the continued application by Judges of Shari'a in the CNT's were indicative of its lack of resonance and meaning amongst local legal practitioners. According to an international expert interviewed in 2009, the international actors responsible for drafting the law were aware of the these potential problems:

These were the sort of things that we talked about at the time and what we very much felt at that time is [that] they won't be able to comply with this, but we shouldn't do something that is dumbed down because this is as high as they would ever go. If you keep the bar high, then at least you give them something to move towards, but what there hasn't been is the sort of

255 Ministry of Justice Justice for All, 2005, available at www.cmi.no/pdf/?file=/ afghanistan/doc/Justice\%20for\%20all\%20MOJ\%20Afgh.pdf [last accessed 19.03.2019]. 
support to actually get it acted upon, get it done by everybody, understood by everybody. It is across the board. It is from the judges down. They just don't understand what the law is there for and how to use it...You have also got huge tribal and religious influences in there [and] they really don't want to get involved in these sort of things. They just don't understand it. It is contrary to everything they have done in the past. ${ }^{256}$

While academic authorities such as Tapper ${ }^{257}$ have suggested that Afghan culture is capable of absorbing new transplanted legal procedures, it appears that those offered by the CNL failed to sufficiently connect to Afghan perceptions of 'justice' to foster the absorption that their draughtspersons might have hoped for.

The 2005 CNL also failed to meet its objectives of preventing poppy cultivation and the trafficking of narcotic drugs and chemical precursors. Some progress was certainly made. With assistance from international partners, precursors bound for heroin producing laboratories in Afghanistan were seized. Furthermore, the CJTF successfully prosecuted cases leading to the conviction of more than 1,500 drug traffickers since its establishment in May 2005 to 2010. Medium and high-level drug traffickers were convicted, their convictions made possible because of the new counter surveillance and intelligence gathering provisions the CNL introduced. However, the impact of these successes on the drug economy in Afghanistan was minimal, and the CNL 2005 did not achieve its stated goal of preventing the cultivation and trafficking of opium poppy. Cultivation and production levels of opium poppy in the first 4 years following the passing of the law exceeded those of any previous equivalent period in Afghanistan's history. Furthermore, it failed to encourage the establishment of treatment, rehabilitation, and harm reduction programmes, and by and large the MCN failed to effectively carry out its mandate under the CNL 2005 to monitor, coordinate and evaluate the Afghan government's counter narcotic policies.

Many of the problems surrounding the law relate to issues that were part of wider social and political dilemmas affecting the general rule of law reform in Afghanistan. A CNT Judge confirmed that 'the problem

256 Interview, supra note 43.

257 Richard Tapper, supra note 72. 
is not with the law, but with the willingness to enforce the laws as they were written. ${ }^{\prime 258}$ The deterioration of the security situation in Afghanistan since 2005 has affected the delivery of the counter narcotics projects. ${ }^{259}$ There were also problems with regard to the capacity of the police, reflected in a 2008 UNODC report that concluded that 'Afghanistan has inadequate and insufficient counter narcotics law enforcement capabilities to respond to the impact of the illicit drug trade. ${ }^{260}$ Police corruption was endemic and thought to be the main reason why more cases were not being received by the CJTF. ${ }^{261}$ A CJTF Judge who convicted a head of highway police in 2009 noted that in his experience 'often the police would let people go if they were paid enough money.' ${ }^{262}$ Not only the police were corrupt. ${ }^{263}$ According to a defence expert based in Kabul in 2010 'there is a lot of corruption in the Counter Narcotics Courts amongst the Judges and the prosecutors. They do not always follow the law. They do what they want. There is corruption in both the provincial and the Counter Narcotics Courts. ${ }^{264}$ In a further interview, this expert claimed that in the context of counter narcotics cases:

The biggest people to get bribes were the police, then the judges. Judges take bribes. There were two groups of judges - one group does take bribes and the other does not. The police take the most bribes and let people go. Police, prosecution and judges collude and get together and find a way to acquit. They would work out a solution for the defendant so that a case collapses or judges were left with no alternative other than to acquit. The judges who accept bribes would back each other up if there is any questioning about their decisions. ${ }^{265}$

${ }^{258}$ CJTF Judge, supra note 94

259 P. Wintour, Opium Economy Would Take 20 years and £1bn To Remove, The Guardian, 6 February 2008.

${ }^{260}$ UNODC, supra note 120 at p.v.

261 Interview, supra note 53.

${ }^{262}$ UNODC, supra note 215 at 140 . The chief of counter narcotics police in Nimroz province was arrested in 2009 in connection with assisting drug trafficking.

${ }^{263}$ Interview, supra note 153. This defence expert states that 'the biggest people to get bribes were the police. The police take the most bribes and let people go.'

264 Ibid.

265 Interview 09.05.2010. 
The Ministry of Interior was a notable source of corruption. In 2007 it was unable to account for up to $30 \%$ of foreign-donated funds and approximately $80 \%$ of its personnel were thought to be benefiting directly from the drug trade. ${ }^{266}$ In fact, the influence of the drug trade was pervasive throughout government departments. By 2008 it was estimated that between $25 \%-40 \%$ of all civil servants working in the Afghan government were profiting from the illicit narcotic industry. ${ }^{267}$ Indeed, the CJTF confirmed that between 2008 and 2009 those prosecuted under the CNL 'included a provincial deputy head of the CNPA, senior civil servants, former Russian commanders and officers in the ANA, ANP, NDS, and the Border Police, ${ }^{268}$ dramatically illustrating the link between state corruption and the narcotics trade. This level of corruption compromised the enforcement of the $\mathrm{CNL}$, the application of which was further impeded by Afghanistan's poor travel infrastructure, insecurity and the limited reach of the state criminal justice system to provincial areas.

While recognising this, arguably some of the problems associated with the CNL were attributable to the fact that it was a legal transplant motivated by a modernising agenda largely devised and implemented by international actors. The necessity of quickly producing suitably 'modern' law resulted in a transplanted law prepared by international actors following minimal local participation with damaging consequences. Opposition by Afghan justice officials to proposals during the drafting stage was reportedly silenced and an international expert involved in the discussions was ordered by the US embassy to refrain from distributing a discussion paper he had prepared comparing the draft provisions with existing Afghan law and legal principles. ${ }^{269}$ Moreover, President Karzai was persuaded by his international partners to invoke his Presidential powers to issue the CNL and consequently avoid debate and scrutiny by the Taqnin. Such law-making processes can increase legitimacy-damaging local perceptions of international imposition.

266 A. Kent, Covering up for Karzai and Co., Policy Options, July-August 2007, p. 11.

267 J. Goodhand, Frontiers and Wars: the Opium Economy in Afghanistan, Agrarian Change, Issue 5, 2005, p. 209.

268 UNODC, supra note 215 at p. 140.

269 M. E. Hartmann, A. Klonowiecka-Milart, supra note 54 at p. 289. 
The knowledge that the architects of the CNL had of Afghanistan's criminal justice and legislative heritage is questionable, ${ }^{270}$ a point to which the MOJ's 2005 Justice for All report was possibly alluding when it objected to the fact that 'very few foreign experts appreciate the uniqueness of Afghan law.'271 Some historical research would have revealed that although positive codified state law was traditionally less significant to Afghanistan's rural communities than customary and Shari'a approaches to justice, there have been periods when the centralised state criminal justice system has been accepted even by the rural population and that this has been the case when the state legal system has absorbed all the country's legal traditions. The last legal system developed solely by the Afghans between 1964 to 1979, which witnessed the passing of the 1965 Code of Criminal Procedure and the 1976 Penal Code, was generally accepted by everyone from rural population to urban elite. The Court system was split between courts that applied religious law and those applying state law. ${ }^{272}$ Judges in primary courts would often refer matters to tribal village elders for resolution in accordance with customary law and incorporate their findings in their own formal decisions. According to Etling this period demonstrated that 'it is possible to mix Islamic and secular laws within one legal system, and ...such a system in Afghanistan increased the legal system's legitimacy and led to wide acceptance by the local population. ${ }^{273}$ This semi-secular system of justice was accepted because it allowed for the inclusion of all of Afghanistan's legal traditions and for interpretation of rules and procedures by the legal authorities responsible in each legal tradition. The transplanted CNL, however, failed to allow for similar negotiations between these legal traditions, resulting in negative repercussions in terms of its reception.

These conclusions suggest that it was unreasonable to develop the CNL by legal transplantation. Its creation by foreign actors (a hallmark

${ }^{270}$ Interview, former senior Italian official who noted that Di Gennaro's knowledge of Afghan law 'was very limited.'

${ }^{271}$ Ministry of Justice, supra note 255 at p. 7.

272 B. Etling, Legal Authorities in the Afghan Legal System (1964-1979), 2003, p. 11, available at www.harvard.edu/programs/ilsp/research/etling.pdf [last accessed 15.03. 2019].

273 Ibid. at p. 12. 
of legal transplants in post-intervention states), its transplanted foreign content, and the international support for enforcing it and supervising its application increased its potential for being regarded as a foreign imposition intent on promoting centralisation based on western models at the expense of local requirements. Wrongly applied transplanted procedures risked increasing local dissatisfaction with the state justice system and the appeal of alternative justice mechanisms, including those offered by the Taliban. The transplanted, international design of the law contributed to the injustices perpetrated by those supposed to be applying its provisions. According to an Afghan defence lawyer, 'the judges and prosecutors get their salaries from the UK embassy, so they just convict people [under the law] to keep them happy. ${ }^{274}$ In addition, a defence expert interviewed in 2010 complained that the CNL '[was] very strict. It [was] not benefitting the general public. It [was] bad for them and the country...for couriers it [was] not right. ${ }^{275}$ While it was introduced as part of a drive to reform Afghanistan's criminal law framework and promote the rule of law, as an unsuccessful legal transplant the CNL was applied inappropriately, becoming a vehicle for arbitrary arrest and detention, bribes and corruption, and consequently adding to frustration and discontent with state criminal justice, capable of exploitation by the Taliban. To that extent, rather than driving justice, it arguably became a catalyst for insurgency.

These findings are informative for scholarly debates on transplant feasibility and the limitations of their use as tools for legal development. They also have important implications for legal reform policy in postintervention states. On the theoretical level, the development and application of the CNL in Afghanistan serves to refute Legrand's pessimism about the impossibility of legal transplants. Moreover, while this analysis lends some credence to Watson's contention that legal transplants are the key building blocks of legal development, tied to the actions of the professional legal community, the experience of the transplanted CNL sits more comfortably with socio-legal perspectives of legal reform that assert that local contextual issues are vital conditioning factors for the

274 Interview senior Afghan defence lawyer.

275 Interview, supra note 155. 
reception of transplanted law than with Watson's claims about the autonomous existence of law and legal development. Ultimately, then, it casts doubt on Watson's premise of a dis-connect between 'legal transplantability' from social influences. Local factors such as corruption by legal personnel and the poor capacity of the police and defence lawyers clearly challenged the application of the transplanted rules and provisions of the CNL. Additionally, the lack of any complimentary relationship between these new imported rules and existing legal infrastructures in Afghanistan impacted on their reception, a finding which aligns with Kanda and Milhaupt's assertion that transplant success is dependent upon the 'fit' between adopted rules and host environments. The 'counter cultural' measures of the CNL were not transplanted into 'the right plot' in this instance. They were too removed from the established legal order and the norms associated with counter-narcotic justice in Afghanistan to take root. This analysis supports deLisle's contention that the successful importation of transplanted law is tied to its approximation to the legal culture of the adopting country.

In practical terms, a number of points emerge from this analysis. Firstly, there is every justification for considering that legal transplants can be engineers for developing criminal law frameworks in post-intervention states. Secondly, sources for readily-available transplantation, such as the Model Codes for Post Conflict Criminal Justice, ${ }^{276}$ can be useful reference points for ensuring the newly introduced modern law that will comply with international human rights norms. However, the Model Codes should only be used for inspiration for legislative material that can then be assessed for 'sensitivity' rather than as tools for producing 'bolt-on' laws that ignore local legal traditions. Thirdly, law reformers should not assume that it is always reasonable to rely on legal transplantation to prepare post-intervention criminal law. The reasonableness of developing legislation in this way requires prior assessment. The cost-saving, 'quick-fix' transplant should, where possible, be avoided. In essence, if transplanted law is expected to travel to post-intervention countries, it should be marked 'handle with care.' Legal transplants are more likely to be considered effective and, indeed, reasonable mechanisms for reform

${ }^{276}$ O'Connor and Rausch, supra note 2. 
if they are employed in ways that are sensitive to the environment of the adopting country. This sensitive transplanting necessitates a full understanding of theoretical discussions on legal transplants as tools for legal reform and the conditioning factors for their success; reflection on the legal traditions of the importing post-intervention state; and consideration of the potential for the law being successfully received, bearing in mind the evaluative criteria applied in this article. This requires the acknowledgement of the limits of the transplant mechanism as a reform tool; of the fact that law is not developed in isolation from the society in which it is enacted and the success of any legal transplant and the reasonableness for relying on the transplant mechanism to develop new law is tied to the way in which is it applied and the extent to which it has achieved its objectives. These variables should form the basis of collaborative work with local legal experts to review the provisions and their suitability for application in the importing country and of the development of complimentary programmes of training and support for law enforcement and criminal justice practitioners before enactment. It also acknowledges that in post-intervention states the challenges that societal influences may have on the success of a new law are likely to be greater, more expansive, and more difficult to overcome.

Recent reform initiatives in Afghanistan support the case for sensitive transplantation. A Criminal Law Working Reform Group (CLWRG) was established in 2006, partly as a reaction to the raft of legislation, including the CNL, passed by Presidential decree in 2004 and 2005 following limited engagement by Afghan legal experts. This group, comprising high level Afghan justice officials representing all the Afghan justice institutions, as well as international representatives from UNODC and UNAMA, reviewed a new draft CPC over the course of a year before its eventual approval. The review process involved weekly meetings to discuss drafted provisions and to propose revisions that were, according to Hartmann 'derived from the knowledge and experience of all its members [and] custom-designed for Afghanistan.' 277 This involved the importation of foreign legal concepts, including provisions relating to covert investigative measures and alternatives to imprisonment, though

277 M. E. Hartmann, A. Klonowiecka-Milart, supra note 54 at p. 294. 
all such transplants were only accepted following discussion and agreement by all participants. ${ }^{278}$ Failing this, explanatory notes were drafted for the benefit of future decision-makers. This process of law reform, which had included transplantation, was praised by the chief of the Ministry of Justice as 'the best drafting ... received from the international community. ${ }^{279}$ It involved transplantation that was sensitive to the vital ingredients of local participation, local context, and the plurality of Afghanistan's legal traditions. The same group is currently engaged with work on a new Penal Code and is also reviewing legislation relating to the support of victims of terrorism. ${ }^{280}$ The fundamental lesson of the $\mathrm{CNL}$ is that while legal transplantation is likely to remain a pervasive aspect of post-intervention criminal law reform, new laws containing wholesale foreign legal provisions are unlikely to be successfully adopted in these environments. Instead, while international experts armed with foreign legal concepts may have much to offer to reform projects in post-intervention states, what is required is, as Hartmann advocates, a 'humble international approach. ${ }^{281}$ This demands processes of sensitive transplanting informed by comparative law analyses, research on local legal traditions, and extensive collaboration with local justice professionals and academics.

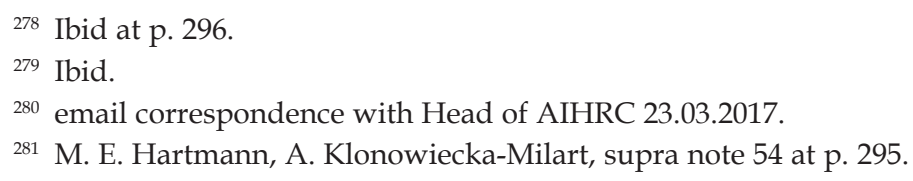

